\title{
Antibacterial, Antifungal, and Antioxidant Activities of Silver Nanoparticles Biosynthesized from Bauhinia tomentosa Linn
}

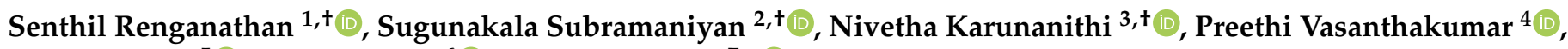 \\ Arne Kutzner ${ }^{5}{ }^{(}$, Pok-Son Kim ${ }^{6}$ and Klaus Heese $7, * \mathbb{C}$
}

check for updates

Citation: Renganathan, S.;

Subramaniyan, S.; Karunanithi, N.; Vasanthakumar, P.; Kutzner, A.; Kim, P.-S.; Heese, K. Antibacterial, Antifungal, and Antioxidant Activities of Silver Nanoparticles Biosynthesized from Bauhinia tomentosa Linn. Antioxidants 2021, 10, 1959. https://doi.org/10.3390/ antiox10121959

Academic Editors: Washington Luiz Esteves Magalhães and Alessandra Cristina Pedro

Received: 5 November 2021 Accepted: 5 December 2021 Published: 7 December 2021

Publisher's Note: MDPI stays neutral with regard to jurisdictional claims in published maps and institutional affiliations.

Copyright: (c) 2021 by the authors. Licensee MDPI, Basel, Switzerland. This article is an open access article distributed under the terms and conditions of the Creative Commons Attribution (CC BY) license (https:/ / creativecommons.org/licenses/by/ $4.0 /)$.
1 Department of Bioinformatics, Marudupandiyar College, Thanjavur 613-403, India; rsenthil@mpi.edu.in

2 Department of Bioinformatics, A.V.C. College, Mayiladuthurai 609-305, India; sugunakala@avccollege.net 3 Department of Biotechnology, A.V.C. College, Mayiladuthurai 609-305, India; nivetha2161998@gmail.com

4 Department of Biotechnology, Bharath College of Science and Management, Thanjavur 613-005, India; preethibiotech2009@gmail.com

5 Department of Information Systems, College of Engineering, Hanyang University, 222 Wangsimni-ro, Seoul 133-791, Korea; kutzner@hanyang.ac.kr

6 Department of Mathematics, Kookmin University, 77 Jeongneung-ro, Seoul 136-702, Korea; pskim@kookmin.ac.kr

7 Graduate School of Biomedical Science and Engineering, Hanyang University, 222 Wangsimni-ro, Seoul 133-791, Korea

* Correspondence: klaus@hanyang.ac.kr

+ These authors contributed equally to the study.

\begin{abstract}
The biogenic synthesis of silver nanoparticles (AgNPs) has a wide range of applications in the pharmaceutical industry. Here, we synthesized AgNPs using the aqueous flower extract of Bauhinia tomentosa Linn. Formation of AgNPs was observed using ultraviolet-visible light spectrophotometry at different time intervals. Maximum absorption was observed after $4 \mathrm{~h}$ at $420 \mathrm{~nm}$ due to the reduction of $\mathrm{Ag}^{+}$to $\mathrm{Ag}^{0}$. The stabilizing activity of functional groups was identified by Fourier-transform infrared spectroscopy. Size and surface morphology were also analyzed using scanning electron microscopy. The present study revealed the AgNPs were spherical in form with a diameter of $32 \mathrm{~nm}$. The face-centered cubic structure of AgNPs was indexed using X-ray powder diffraction with peaks at $2 \theta=37^{\circ}, 49^{\circ}, 63^{\circ}$, and $76^{\circ}$ (corresponding to the planes of silver 111, 200, 220, 311), respectively. Energy-dispersive X-ray spectroscopy revealed that pure reduced silver $\left(\mathrm{Ag}^{0}\right)$ was the major constituent (59.08\%). Antimicrobial analyses showed that the biosynthesized AgNPs possess increased antibacterial activity (against Staphylococcus aureus (Gram-positive) and Escherichia coli (Gram-negative), with larger zone formation against S. aureus $(9.25 \mathrm{~mm})$ compared with that of E. coli $(6.75 \mathrm{~mm})$ ) and antifungal activity (against Aspergillus flavus and Candida albican (with superior inhibition against A. flavus (zone of inhibition: $7 \mathrm{~mm}$ ) compared with C. albicans (zone of inhibition: $5.75 \mathrm{~mm}$ )). Inhibition of 2,2-diphenyl-1-picrylhydrazyl (DPPH) radical scavenging activity was found to be dose-dependent with half-maximal inhibitory concentration $\left(\mathrm{IC}_{50}\right)$ values of $56.77 \mu \mathrm{g} / \mathrm{mL}$ and $43.03 \mu \mathrm{g} / \mathrm{mL}$ for AgNPs and ascorbic acid (control), respectively, thus confirming that silver nanoparticles have greater antioxidant activity than ascorbic acid. Molecular docking was used to determine the mode of antimicrobial interaction of our biosynthesized $B$. tomentosa Linn flower-powder extract-derived AgNPs. The biogenic AgNPs preferred hydrophobic contacts to inhibit bacterial and fungal sustainability with reducing antioxidant properties, suggesting that biogenic AgNPs can serve as effective medicinal agents.
\end{abstract}

Keywords: antioxidant; bauhinia tomentosa; free radicals; microbial; nanoparticle; reactive oxygen species (ROS); silver

\section{Introduction}

Resistance to antibiotics and a wide variety of microorganisms in the public health system has become a major obstacle, and almost every single variant of microorganisms has 
developed antibiotic resistance [1,2]. According to contemporary ideas, nanoparticles, such as silver nanoparticles (AgNPs), can inhibit the growth of microbes [3-5]. Nanoparticles are structures with dimensions ranging from approximately 1 to $100 \mathrm{~nm}$ that exhibit significantly different physical (mechanical, optical, electrical) and chemical properties when compared with their larger counterparts [6,7]. Over the past 10 to 20 years, metal nanoparticles, and AgNPs in particular, have attracted attention due to their versatility and broad range of industrial and biomedical applications [8-11]. Potential uses include antimicrobial (antibacterial, antifungal, and antiviral) agents [12-17], biomedical device coatings, drug-delivery carriers, and imaging probes for diagnostic and optoelectronic applications [18-22]. AgNPs could mediate the antimicrobial activity by producing reactive oxygen species and free radicals causing cell wall damage, lipid peroxidation, protein denaturation, and nucleic acid and proton pump damage $[4,23]$. The use of biological methods and natural resources to synthesize AgNPs has increased considerably due to improved feasibility and high biocompatibility [22,24-26]. Biological synthetic pathways based on microorganisms or plant extracts have been widely explored for the production of AgNPs in several applications as they are environmentally friendly and often inexpensive. Moreover, plant-based extract-mediated AgNPs synthesis is more advantageous than other biological processes because it does not require stringent aseptic environments and strict monitoring of cell culture conditions [27-34]. The genus Bauhinia is a member of the Leguminosae family (subfamily Caesalpiniaceae) and consists of about 300 species. Bauhinia tomentosa is a South Indian shrub that has been applied in ayurvedic medicine for centuries based on its multiple beneficial effects, including antioxidant, anti-inflammatory, antitumor, antimicrobial, antiamoebic, antidiabetic, and antirheumatic properties as well as functioning as an analgesic and hypocholesterolemic agent [35-39]. Additionally, its extracts contain a diverse set of metabolites that could be possibly used in the reduction of silver ions, as a capping and stabilizing agent in the synthesis of nanoparticles [35,40-42]. Biological synthetic methods can produce AgNPs that are frequently more stable and less toxic than nanoparticles obtained using conventional methods [7,34,41,43-47]. The surface of green synthesized AgNPs has strong bioactive antioxidant and antimicrobial activity [34].

For the study of the potential mechanism of AgNPs-mediated antimicrobial effects, we selected DNA gyrase, cytochrome P450, and dihydrofolate reductase as potential candidate target proteins. DNA gyrase is categorized as topoisomerase II, an ATP-dependent enzyme involved in DNA transcription, replication, and chromosome segregation in Gram-negative and Gram-positive bacteria. In eukaryotes, cytochrome P450 catalyzes a variety of reactions and is an important enzyme in fungal primary and secondary metabolism. The cytochrome P450 enzyme is required for sterol biosynthesis in eukaryotic cells and is also the primary target of clinical drugs used to treat fungal pathogens. In addition, dihydrofolate reductase is a member of the reductase enzyme family, which is found in all living organisms and is required for fungal cell growth and proliferation. Thus, DNA gyrase, cytochrome P450, and dihydrofolate reductase are considered major therapeutic targets in drug delivery and design [48-51].

Accordingly, in the current study we biosynthesized AgNPs using B. tomentosa Linn flower powder extract as a natural source. We validated their antimicrobial activity and evaluated possible mechanisms of action via molecular docking analysis using DNA gyrase, cytochrome P450, and dihydrofolate reductase, respectively.

\section{Materials and Methods}

\subsection{Materials}

All chemicals used in this research, including antibiotics such as chloramphenicol, fluconazole, and silver nitrate $\left(\mathrm{AgNO}_{3}\right)$, were of analytical grade and were purchased from Sigma-Aldrich (St. Louis, MO, USA). 


\subsection{Origin of B. tomentosa Linn flowers}

B. tomentosa Linn flowers were collected from Sirkazhi (Nagapattinam District, Tamil $\mathrm{Nadu}$, India; $11.2420^{\circ} \mathrm{N}, 79.7287^{\circ} \mathrm{E}$ ), in December 2019. (An authenticated voucher specimen, No. 374, was deposited in the herbarium of the Department of Botany, Annamalai University, Chidambaram, Tamil Nadu, India). Plant material was washed with normal and distilled water, dried in the dark at room temperature, and ground to a fine powder, as described previously [52-54]. Ground B. tomentosa Linn flower powder (20 g) was soaked in distilled water for $24 \mathrm{~h}$ with mild shaking at room temperature, boiled for $10 \mathrm{~min}$, filtered using Whatman grade 1 filter paper (Sigma-Aldrich), and concentrated by a rotary vacuum evaporator at $20^{\circ} \mathrm{C}$ (EQUITRON, rotatory vacuum evaporator, Medica Instrument MFG. Co, Chennai, Tamil Nadu, India) to $1 \mathrm{mg} / \mathrm{mL}$. Concentrated B. tomentosa Linn flower powder extract was stored at $4{ }^{\circ} \mathrm{C}$ until further use [54].

\subsection{Preliminary Phytochemical Analysis}

Qualitative phytochemical characterization of B. tomentosa Linn flower powder extracts (using $70 \%$ to $100 \%$ alcohol (methanol, ethanol), distilled water, or petroleum ether) followed established protocols described by Harborne [55] to identify and characterize the phytochemical constituents (including anthraquinones, coumarins, polyphenol, terpenoids, saponins, tannins, steroids, alkaloids, flavonoids, glycosides, triterpenoids, and terpenoids), as described previously [54,55].

\subsection{Bacterial and Fungal Cultures}

All bacterial and fungal cells were obtained from the Microbial Type Culture Collection and Gene Bank (MTCC) at the Institute of Microbial Technology, Chandigarh 160036, India. Species used included Escherichia coli (MTCC 732), Staphylococcus aureus (MTCC 3160), Candida albicans (MTCC 183), and Aspergillus flavus (MTCC 10180). The bacterial cultures were grown routinely in Luria Bertani broth and incubated at $37^{\circ} \mathrm{C}$ (Technico Incubator, Model TLPPL 104, Technico Laboratory Products Pvt. Ltd., Chennai, Tamil Nadu, India). Fungal cultures were grown similarly on potato dextrose agar (PDA) and incubated at $27^{\circ} \mathrm{C}$ for 7 days.

\subsection{Synthesis of Silver Nanoparticles}

A crude extract $(5 \mathrm{~mL})$ of $B$. tomentosa Linn flower powder was transferred into $45 \mathrm{~mL}$ of a $1 \mathrm{mM}$ aqueous $\mathrm{AgNO}_{3}$ solution in an Erlenmeyer flask. The flask was incubated in the dark at room temperature for $5 \mathrm{~h}$ to minimize photoactivation of silver nitrate. The AgNP solution was purified by repeated centrifugation at 10,000 rpm for $15 \mathrm{~min}$ (REMI-C-30BL, Centrifuge, REMI Electrotecnik Limited, Chennai, Tamil Nadu, India) followed by washing of the pellets with deionized water and finally drying to collect the AgNPs [56-58].

\subsection{Characterization of Silver Nanoparticles}

The confirmation of biosynthesized B. tomentosa Linn flower powder-extract-derived AgNPs was accomplished using ultraviolet-visible light (UV-vis) spectrophotometry (Lambda 265, Perkin Elmer Health Sciences Pvt. Ltd., Chennai, Tamil Nadu, India; range: 300-800 nm) [58]. Characterization of AgNPs through Fourier-transform infrared spectroscopy (FTIR, Perkin Elmer FTIR-Spectrometer 1725 X, Perkin Elmer Health Sciences Pvt. Ltd., Chennai, Tamil Nadu, India) was used to detect the characteristic peaks of the functional groups attached to the surface of AgNPs in a spectral range of 400 to $4000 \mathrm{~cm}^{-1}[59,60]$. Scanning electron microscopy (SEM) was used to study morphological information on the sample at the submicron scale and elemental information at the micron scale [61,62]. The dried samples were coated with gold (Polaron Emitech SC7640 sputter coater, Quorum Technologies Ltd., Newhaven, East Sussex, UK), and microscopic images were taken at $250 \times$ and a voltage of $10 \mathrm{kV}$ by a Jeol JSM-6480LV SEM machine (JEOL Ltd., Tokyo, Japan) to characterize the particle size and morphology of the AgNPs. Energy-dispersive X-ray (EDX) analysis helped determine the elemental composition of 
the AgNPs [63]. X-ray powder diffraction (XRD) was applied for phase identification of the $\mathrm{Cu} \mathrm{K} \alpha$ radiation (1.5405 $\AA$ ) of the AgNPs (Philips PANanalytical X'Pert XRD System (model \# 3040), Amsterdam, The Netherlands) [57,64].

\subsection{Antimicrobial Activities of Biosynthesized AgNPs}

\subsubsection{Antibacterial Activity}

The antibacterial activity of biosynthesized B. tomentosa Linn flower-powder extractderived AgNPs was investigated against Gram-negative (E. coli) and Gram-positive (S. aureus) bacterial pathogens using agar disk diffusion $[28,56,61,65,66]$. Briefly, a nutrient agar medium was prepared in a Petri dish and the bacterial cultures were swabbed on test media with a sterile cotton swab. The discs were dipped with the following four components $(30 \mu \mathrm{L}$ ): (i) biosynthesized AgNPs, (ii) B. tomentosa Linn flower powder extract, (iii) $\mathrm{AgNO}_{3}$ solution, and (iv) standard antibiotic solutions (chloramphenicol, $30 \mu \mathrm{g} / \mathrm{mL}$ ). The dried discs were pressed gently over the surface of the culture-swabbed medium at equal distances to avoid overlapping of the inhibition zones. The plates were then incubated at $37^{\circ} \mathrm{C}$ for $24 \mathrm{~h}$. After incubation, the antibacterial activity of the biosynthesized AgNPs was evaluated according to the diameters of the clear inhibition zones [67].

\subsubsection{Antifungal Activity}

Antifungal activity of biosynthesized $B$. tomentosa Linn flower-powder extract-derived AgNPs was analyzed against $A$. flavus and $C$. albicans by disk diffusion. The following four different components $(30 \mu \mathrm{L})$ were applied on separate Whatman No. 1 filter paper discs $6 \mathrm{~mm}$ in diameter: (i) biosynthesized AgNPs, (ii) B. tomentosa Linn. flower powder extract, (iii) $\mathrm{AgNO}_{3}$ solution, and (iv) standard antifungal solution (fluconazole, $30 \mu \mathrm{g} / \mathrm{mL}$ ). Each was allowed to dry before being placed on a PDA medium carrying the fungal strains and then incubated for $48 \mathrm{~h}$. The diameter of the zones was measured in centimeters with the help of a scale, and the results were tabulated $[28,58,68,69]$.

\subsection{In Vitro Determination of Antioxidant Activity}

For antioxidant activity testing, every $1 \mathrm{~mL}$ of different concentrations $(20,40,60$, and $80 \mu \mathrm{g} / \mathrm{mL}$ ) of biosynthesized B. tomentosa Linn flower-powder extract-derived AgNPs was mixed with $2 \mathrm{~mL}$ of freshly prepared 2,2-diphenyl-1-picrylhydrazyl solution (DPPH, $1 \mathrm{mM}$ in methanol) and mixed meticulously. After the solution was incubated at room temperature, the absorbance of the solution was recorded at $517 \mathrm{~nm}$ using a UV-vis spectrophotometer (Lambda 265, Perkin Elmer). The free-radical scavenging activity was calculated as: $[($ absorbance at blank $)-($ absorbance at test $) /($ absorbance at blank $)] \times 100$ [66] .

\subsection{Molecular Docking of Silver Nanoparticles}

The structures of target proteins and small molecules (AgNPs, chloramphenicol, and fluconazole) were retrieved from the Protein Data Bank (PDB) and the PubChem database, respectively (PDB IDs: 3G7B [DNA gyrase, S. aureus], 4WUB [DNA gyrase, E. coli], 5TZI [cytochrome P450, C. albicans], and 6DRS [dihydrofolate reductase, A. flavus]). Molecular docking of AgNPs with receptors was accomplished through a Patch dock server (http:/ / bioinfo3d.cs.tau.ac.il/PatchDock, accessed on 25 October 2021). The root-meansquare deviation was set at $4 \AA$, and receptor-ligand molecules were used for docking. Based on the scoring and interaction information, the top-ranked complexes were chosen for interaction studies and finding residues [54,70-74].

\subsection{Statistical Analysis}

Experiments were performed in at least three biological replicates (antibacterial, antifungal, and antioxidant assays) and data are presented as mean \pm standard deviation. A Student's t test was applied using SPSS software (IBM SPSS Statistics; Armonk, NY, USA) [75]. 


\section{Results}

\subsection{Phytochemical Analysis}

Qualitative phytochemical screening analysis of B. tomentosa Linn flower-powder extracts identified the phytochemical constituents in the alcohol and aqueous extracts. Aqueous extracts contained alkaloids, anthraquinone, coumarins, flavonoids, glycosides, polyphenol saponins, steroids, tannin, terpenoids, and triterpenoids. Alcoholic extracts did not obtain tannin (Table 1).

Table 1. Phytochemicals present in aqueous and alcoholic extracts of B. tomentosa Linn.

\begin{tabular}{cccc}
\hline S. No. & Test & Aqueous Extract & Alcohol Extract \\
\hline 1 & Alkaloids & + & + \\
\hline 2 & Antroquinone & ++ & + \\
\hline 3 & Coumarins & ++ & + \\
\hline 4 & Flavonoids & ++ & + \\
\hline 5 & Glycoside & + & + \\
\hline 6 & Polyphenol & ++ & + \\
\hline 7 & Saponin & ++ & + \\
\hline 8 & Steroids & ++ & + \\
\hline 9 & Tannin & + & + \\
\hline 10 & Terpenoids & + & \\
\hline 11 & Triterpenoids & + & \\
\hline Note: ${ }^{\prime \prime}+{ }^{\prime \prime}$ present ${ }^{\prime \prime}++^{\prime \prime}=$ strongly present, ${ }^{\prime \prime}=$ absent. & & + \\
\hline
\end{tabular}

\subsection{Biosynthesis of $A g N P s$}

Biosynthesis of $B$. tomentosa Linn flower-powder extract-derived AgNPs was monitored via the redox reaction (reduction of silver ions to metal and the formation of AgNPs) as recorded by UV-vis spectrophotometry (Figure 1). Over a period of $4 \mathrm{~h}$ the absorption peak shifted from approximately $400 \mathrm{~nm}$ to $420 \mathrm{~nm}$ due to the reduction of $\mathrm{Ag}^{+}$to $\mathrm{Ag}^{0}$ (color shift from brown to yellowish), indicating that AgNPs were obtained.
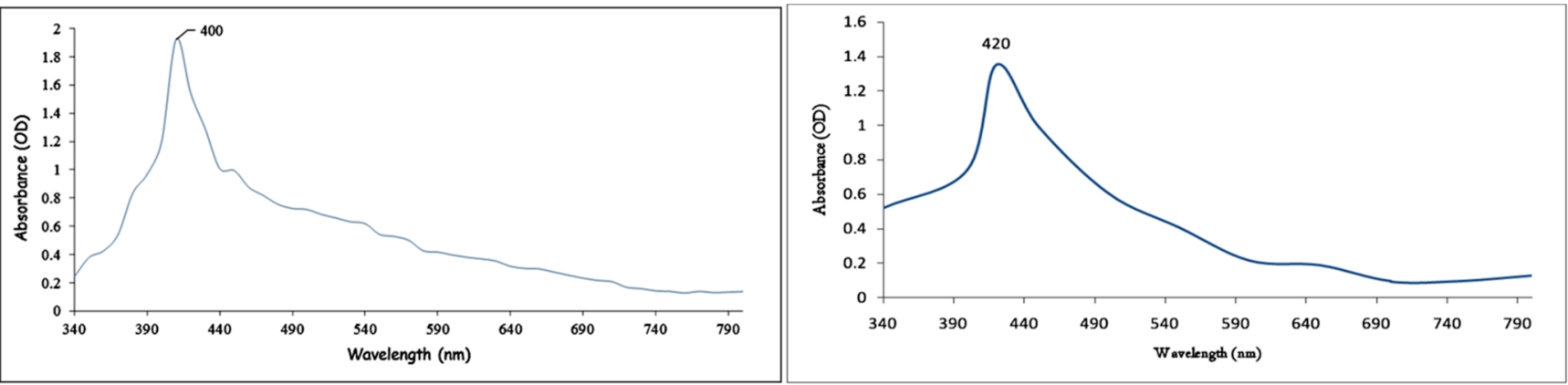

Figure 1. UV-vis spectra of biosynthesized Bauhinia tomentosa Linn flower-powder extract-derived AgNPs $0 \mathrm{~h}$ (left) and $4 \mathrm{~h}$ (right) of incubation of $B$. tomentosa Linn flower powder extract with $\mathrm{AgNO}_{3}$. Over a period of $4 \mathrm{~h}$ the absorption peak shifted from approximately $400 \mathrm{~nm}$ to $420 \mathrm{~nm}$ due to the reduction of $\mathrm{Ag}^{+}$to $\mathrm{Ag}^{0}$, indicating that $\mathrm{AgNPs}$ were obtained.

\subsection{Fourier-Transform Infrared Analysis of Biosynthesized AgNPs}

FTIR spectroscopy (in a range from 400 to $4000 \mathrm{~cm}^{-1}$ ) was used to detect functional groups in biosynthesized B. tomentosa Linn flower-powder extract-derived AgNPs. Characteristic absorption peaks corresponding to the functional groups of secondary metabolites, such as aliphatic primary amine $\left(\mathrm{N}-\mathrm{H}\right.$ bonds, peak at $\left.3227.92 \mathrm{~cm}^{-1}\right)$, terminal alkyne $\left(\mathrm{C}=\mathrm{C}\right.$ bonds, peak at $\left.2099.24 \mathrm{~cm}^{-1}\right)$, imine/oxime $\left(\mathrm{C}=\mathrm{N}\right.$ bonds, peak at $\left.1263.68 \mathrm{~cm}^{-1}\right)$, 
ether (C-O bond, peak at $\left.1187.09 \mathrm{~cm}^{-1}\right)$ and aliphatic bromo components ( $\mathrm{C}-\mathrm{Br}$ bond, peak at $\left.1081.58 \mathrm{~cm}^{-1}\right)$, were evident. Formation of reduced silver atoms $\left(\mathrm{Ag}^{0}\right.$, peaks at $706.63 \mathrm{~cm}^{-1}$ to $408.76 \mathrm{~cm}^{-1}$ ) and capping of the synthesized AgNPs by the phytochemicals present in the extract were also observed (Figure 2).

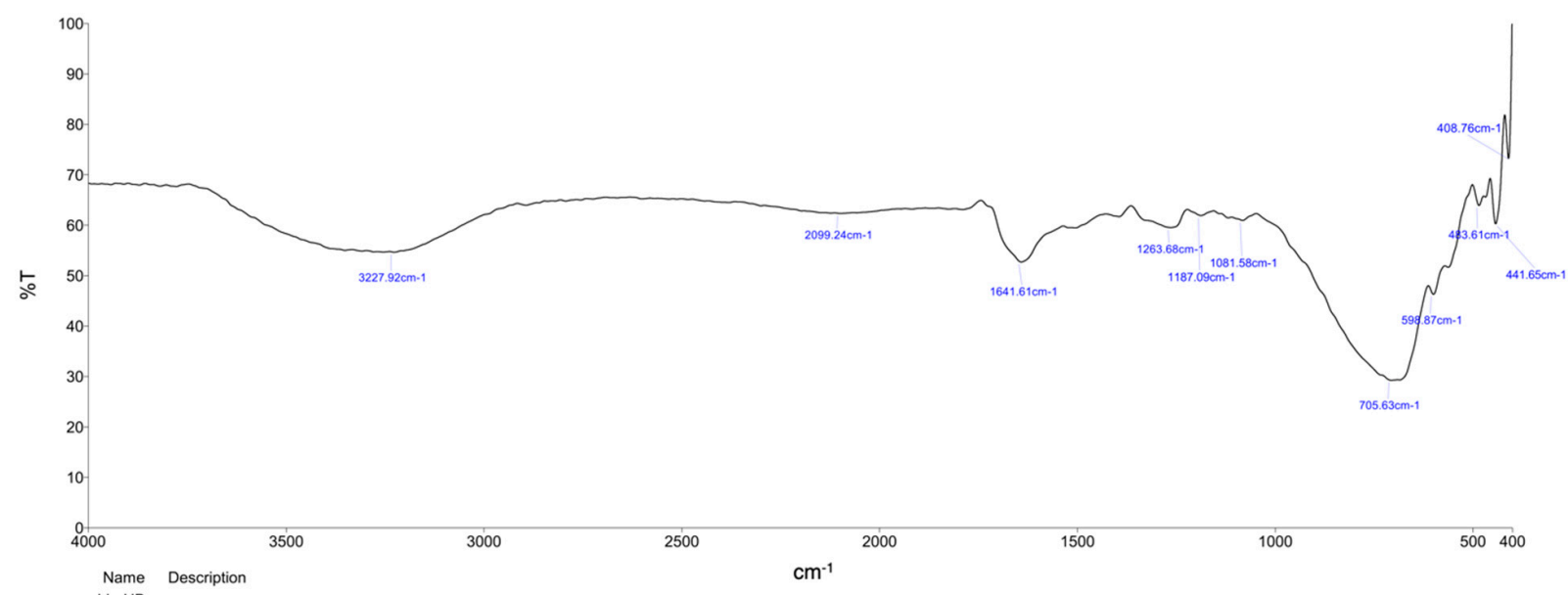

Figure 2. FTIR spectrum of biosynthesized Bauhinia tomentosa Linn flower-powder extract-derived AgNPs. Characterisitc peaks indicated the presence of aliphatic primary amine $\left(\mathrm{N}-\mathrm{H}\right.$ bonds, peak at $\left.3227.92 \mathrm{~cm}^{-1}\right)$, terminal alkyne $(\mathrm{C}=\mathrm{C}$ bonds, peak at $\left.2099.24 \mathrm{~cm}^{-1}\right)$, imine/oxime $\left(\mathrm{C}=\mathrm{N}\right.$ bonds, peak at $\left.1263.68 \mathrm{~cm}^{-1}\right)$, ether $\left(\mathrm{C}-\mathrm{O}\right.$ bond, peak at $\left.1187.09 \mathrm{~cm}^{-1}\right)$ and aliphatic bromo components (C-Br bond, peak at $1081.58 \mathrm{~cm}^{-1}$ ) and also indicate the formation of reduced silver atoms $\left(\mathrm{Ag}^{0}\right.$, peaks at $706.63 \mathrm{~cm}^{-1}$ to $\left.408.76 \mathrm{~cm}^{-1}\right)$.

\subsection{Energy-Dispersive Spectroscopy Analysis of Biosynthesized AgNPs}

An EDX analysis of biosynthesized B. tomentosa Linn flower-powder extract-derived AgNPs revealed signal energy peaks for silver atoms in a range of 2-4 keV, with weaker signals for chloride; pure silver $(59.08 \%)$ was the major element compared to chloride (41.92\%) (Figure 3 and Table 2).

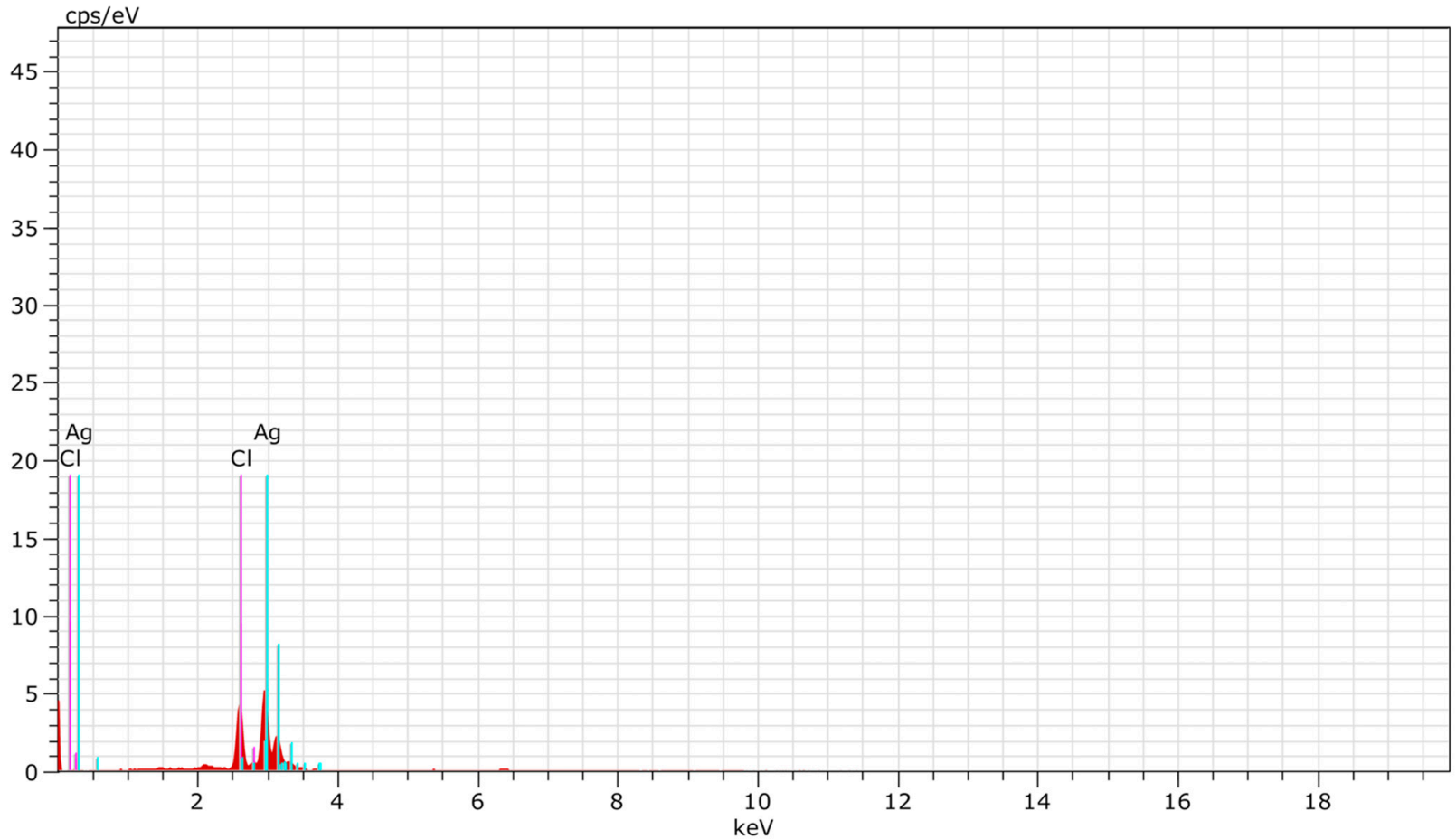

Figure 3. EDX spectroscopy spectrum of biosynthesized Bauhinia tomentosa Linn flower-powder extract-derived AgNPs. Signals for AgNPs appear at the expected position of $3 \mathrm{keV}$. 
Table 2. EDX elemental composition of biosynthesized B. tomentosa Linn flower-powder extractderived AgNPs.

\begin{tabular}{ccccc}
\hline Elements & $\begin{array}{c}\text { Atomic Number } \\
\text { (Periodic Table of Elements) }\end{array}$ & Shells & Weight \% & Atomic \% \\
\hline Ag & 47 & L-series & 75.86 & 59.08 \\
\hline Cl & 17 & K-series & 25.14 & 41.92 \\
\hline Total & & & 100 & 100 \\
\hline
\end{tabular}

Strong signals of silver (59.08\%) are clearly visible in the spectrum. The other signals can be attributed to the organic capping layer. The significant intensity of the peaks indicates the presence of a sufficient coating layer on the biosynthesized AgNPs [27,61,76].

The data indicate the successful biosynthesis of AgNPs with some amount of chlorine impurities [77].

\subsection{X-ray Diffraction Analysis of Biosynthesized AgNPs}

The XRD method was used to determine the crystalline phase of the biosynthesized $B$. tomentos $a$ Linn flower-powder extract-derived AgNPs. The XRD pattern includes diffraction peaks at $2 \theta=37^{\circ}, 49^{\circ}, 63^{\circ}$, and $76^{\circ}$, corresponding to the planes of silver $(111,200,220$, 311 ), respectively (Figure 4). The XRD data and pattern confirmed the crystalline structure of the biosynthesized AgNPs. No significant peaks corresponding to other crystalline phase impurities were detected. All peaks in the XRD pattern can be assumed to correspond with the structure of silver.

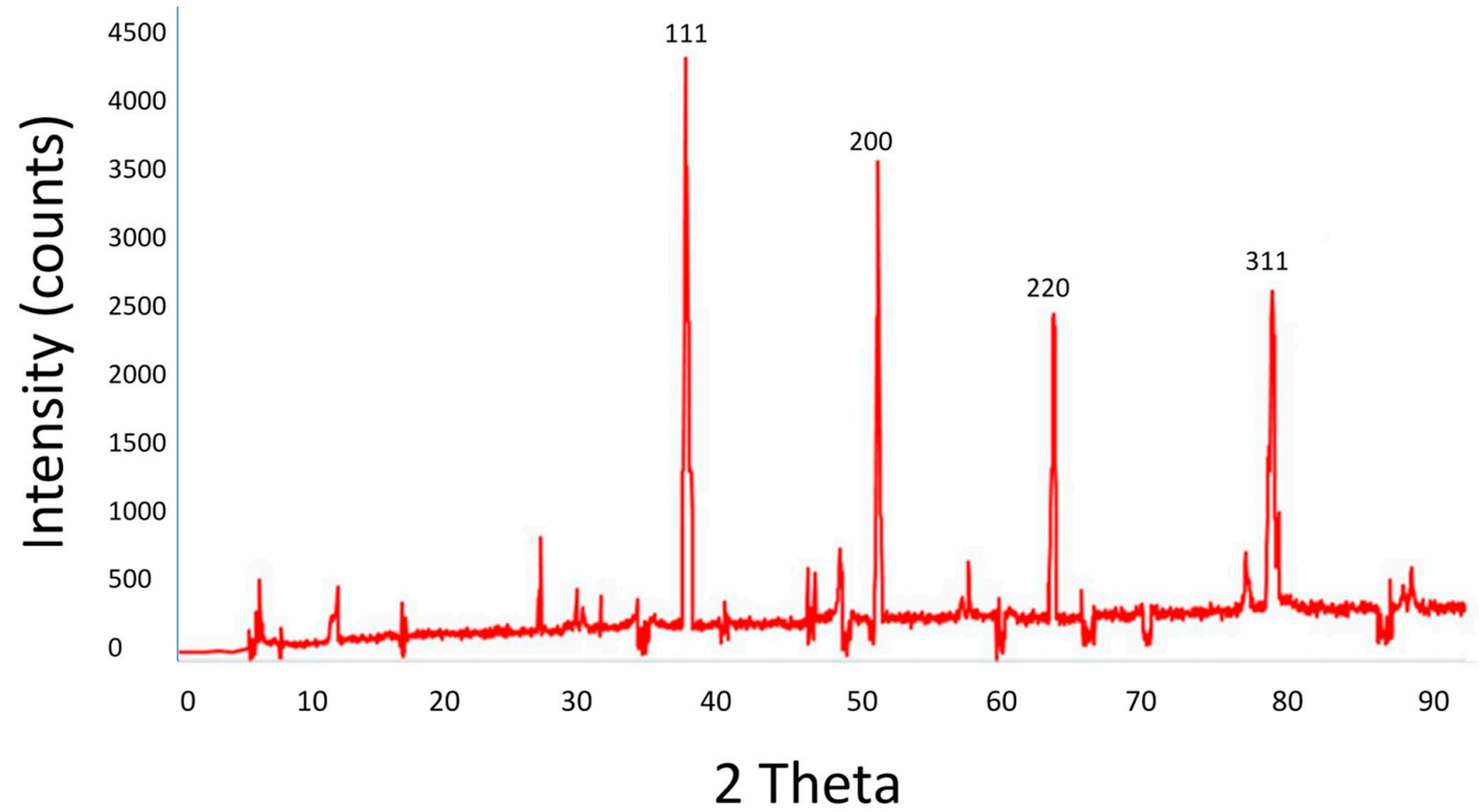

Figure 4. XRD patterns of biosynthesized Bauhinia. tomentosa Linn flower-powder extract-derived AgNPs. The XRD pattern displays diffraction peaks at $2 \theta=37^{\circ}, 49^{\circ}, 63^{\circ}$, and $76^{\circ}$ (corresponding to the planes of silver 111, 200, 220, 311), respectively. The XRD data and pattern confirmed the crystalline structure of biosynthesized AgNPs. No significant peaks corresponding to other crystalline phase impurities were detected.

\subsection{Scanning Electron Microscopic Analysis Biosynthesized AgNPs}

An SEM analysis revealed uniformly distributed AgNPs on the surfaces of the nanoparticles. An SEM image of silver nanoparticles synthesized using B. tomentosa Linn flower extract shows spherical and relatively uniform shapes with a diameter near $32 \mathrm{~nm}$ (Figure 5). 


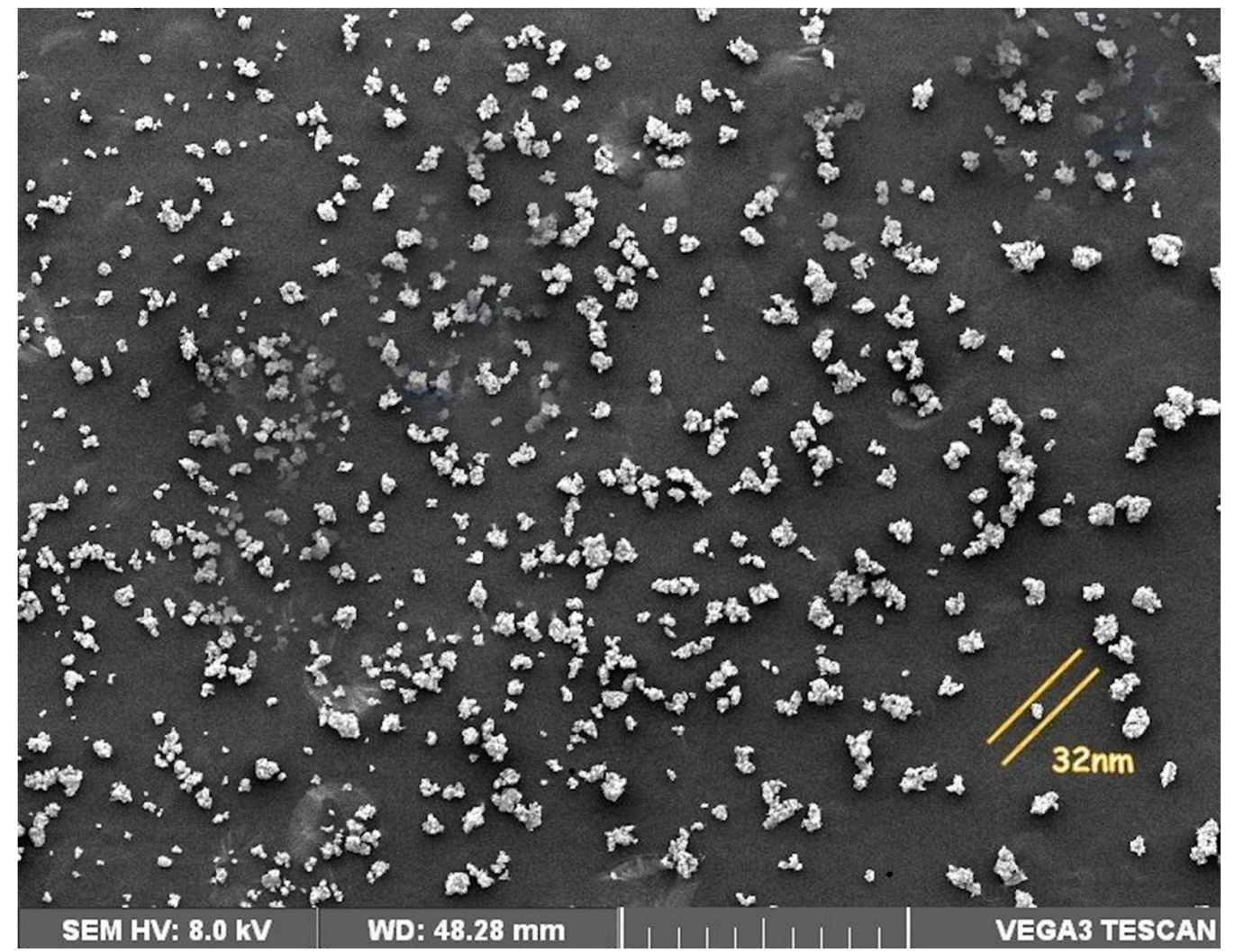

Figure 5. SEM analysis of biosynthesized Bauhinia tomentosa Linn flower-powder extract-derived AgNPs.

\subsection{Antibacterial Activity of Biosynthesized AgNPs}

The antibacterial activity of the biosynthesized AgNPs was determined using disk diffusion. The antibacterial activity of the biosynthesized AgNPs tested against Gram-negative (E. coli) and Gram-positive (S. aureus) bacterial pathogens showed a larger zone of formation against $S$. aureus $(9.25 \mathrm{~mm} \pm 0.956 \mathrm{~mm})$ compared with that of E. coli $(6.75 \mathrm{~mm} \pm 0.957 \mathrm{~mm})$ (Figures 6 and 7).
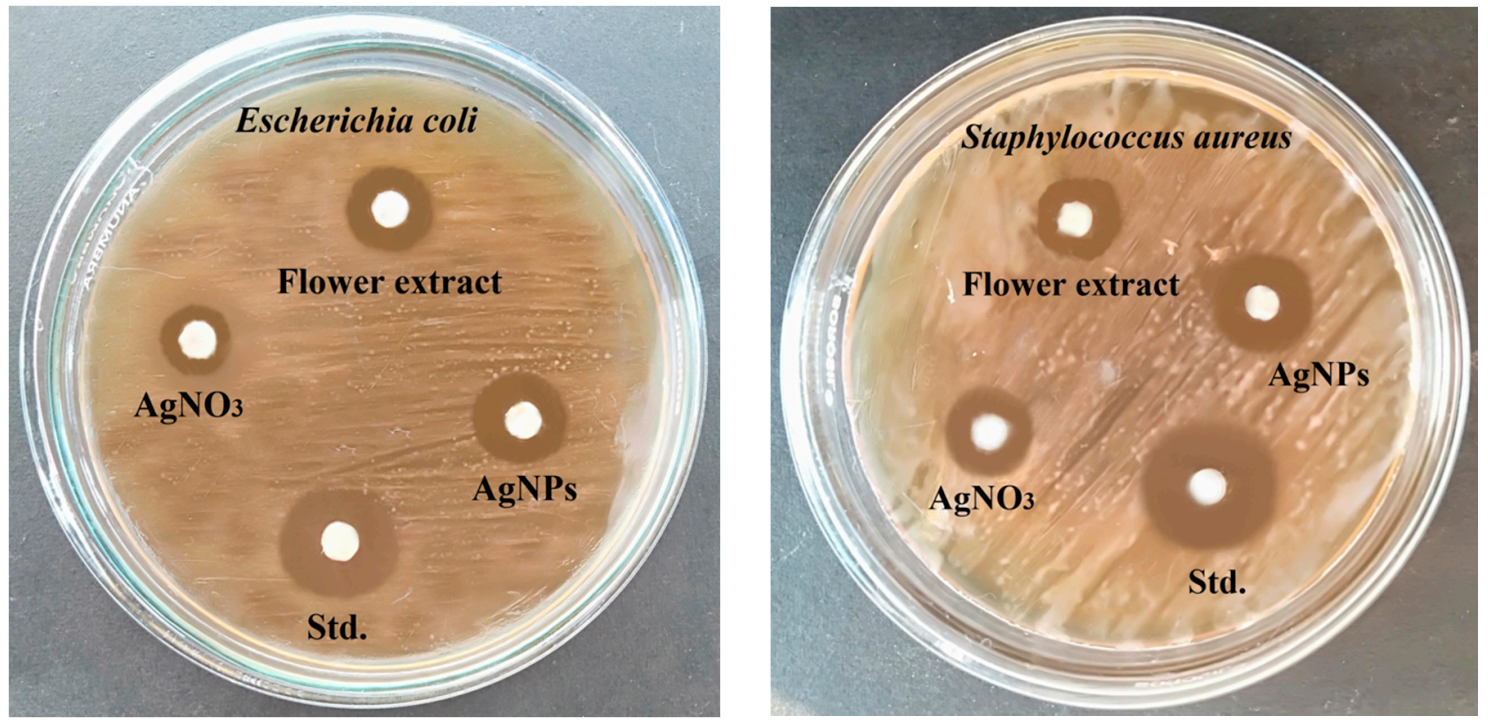

Figure 6. Qualitative antibacterial (Escherichia coli (left) and Staphylococcus aureus (right)) activity of biosynthesized B. tomentosa Linn flower-powder extract-derived AgNPs. The discs were dipped with the following four different components (30 $\mu \mathrm{L}$ ): (i) biosynthesized AgNPs, (ii) Bauhinia tomentosa Linn flower powder extract, (iii) $\mathrm{AgNO}_{3}$ solution, and (iv) standard antibiotic solutions (chloramphenicol, $30 \mu \mathrm{g} / \mathrm{mL}$ ). 


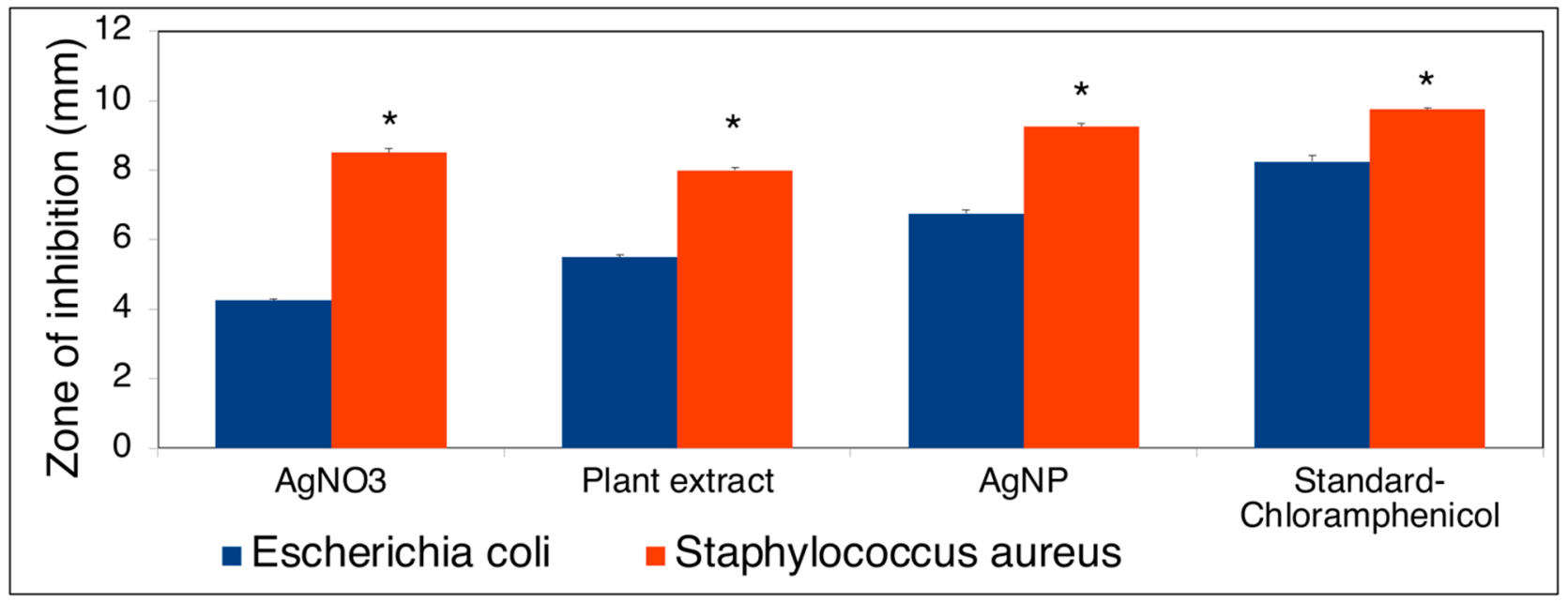

Figure 7. Quantitative antibacterial (Escherichia coli (blue) and Staphylococcus aureus (red)) activity (measurements of zone inhibition activity) of biosynthesized Bauhinia tomentosa Linn flower-powder extract-derived AgNPs (as shown in Figure 6). Data are presented as mean \pm standard deviation of four independent experiments $*^{*} p<0.01$ [E. coli compared with S. aureus]). AgNP has the same efficacy as chloramphenicol.

\subsection{Antifungal Activity of Biosynthesized AgNPs}

The antifungal activity of biosynthesized $B$. tomentosa Linn flower-powder extractderived AgNPs was determined by disk diffusion against the fungal strains $A$. flavus and C. albicans. Fluconazole was used as a standard antifungal agent. The AgNPs achieved superior inhibition against $A$. flavus (zone of inhibition: $7 \pm 0.812 \mathrm{~mm}$ ) compared with $C$. albicans (zone of inhibition $5.75 \pm 0.447 \mathrm{~mm}$ ) (Figures 8 and 9).
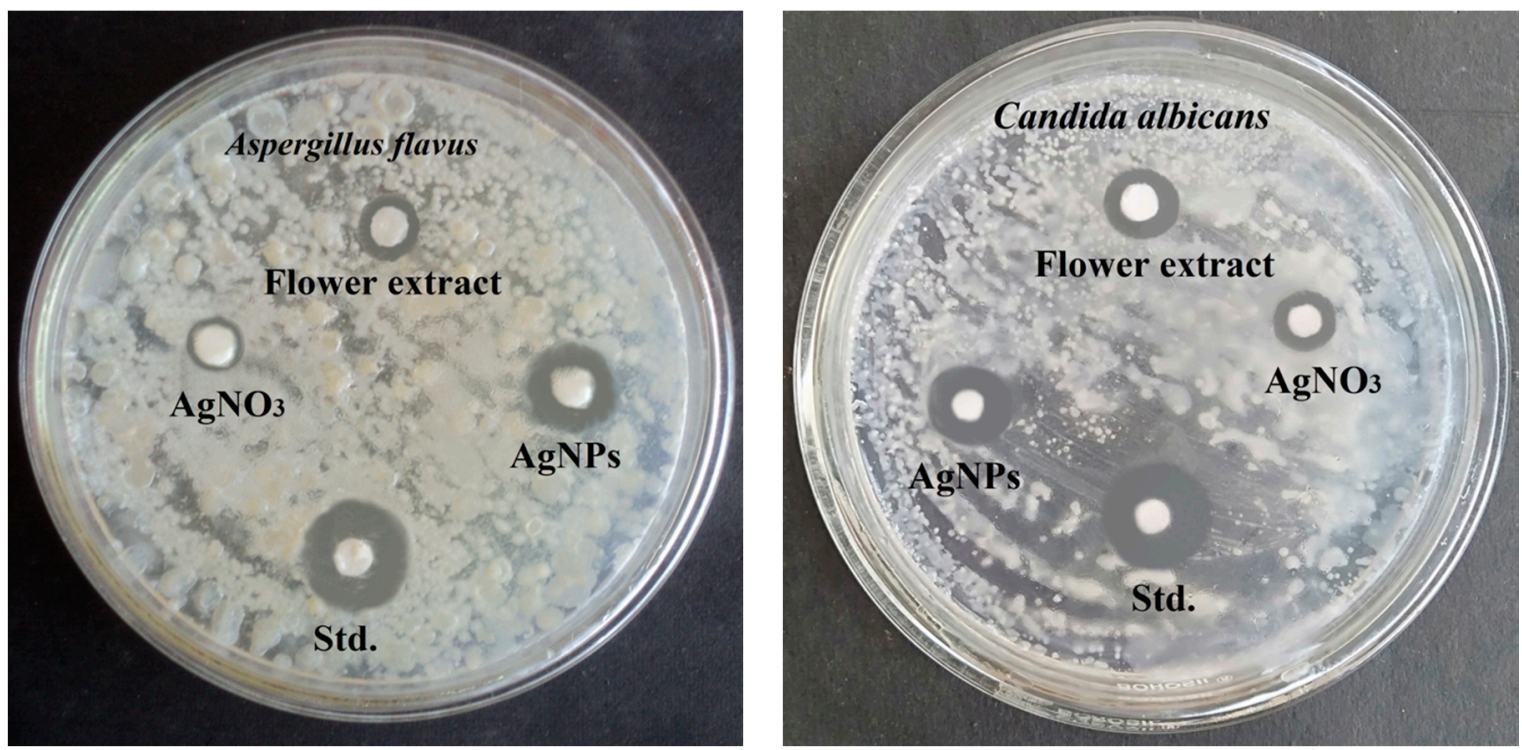

Figure 8. Qualitative antifungal activity of of biosynthesized Bauhinia tomentosa Linn flower-powder extract-derived AgNPs against fungal strains Aspergillus flavus (left) and Candida albicans (right). The following four different components (30 $\mu \mathrm{L})$ were applied on separate Whatman No. 1 filter paper discs $6 \mathrm{~mm}$ in diameter: (i) biosynthesized AgNPs, (ii) Bauhinia tomentosa Linn flower powder extract, (iii) $\mathrm{AgNO}_{3}$ solution, and (iv) standard antifungal solution (fluconazole, $30 \mu \mathrm{g} / \mathrm{mL}$ ), which were allowed to dry before being placed on a potato dextrose agar medium carrying the fungal strains and incubated for $48 \mathrm{~h}$. The diameters of the zones were measured in centimeters. 


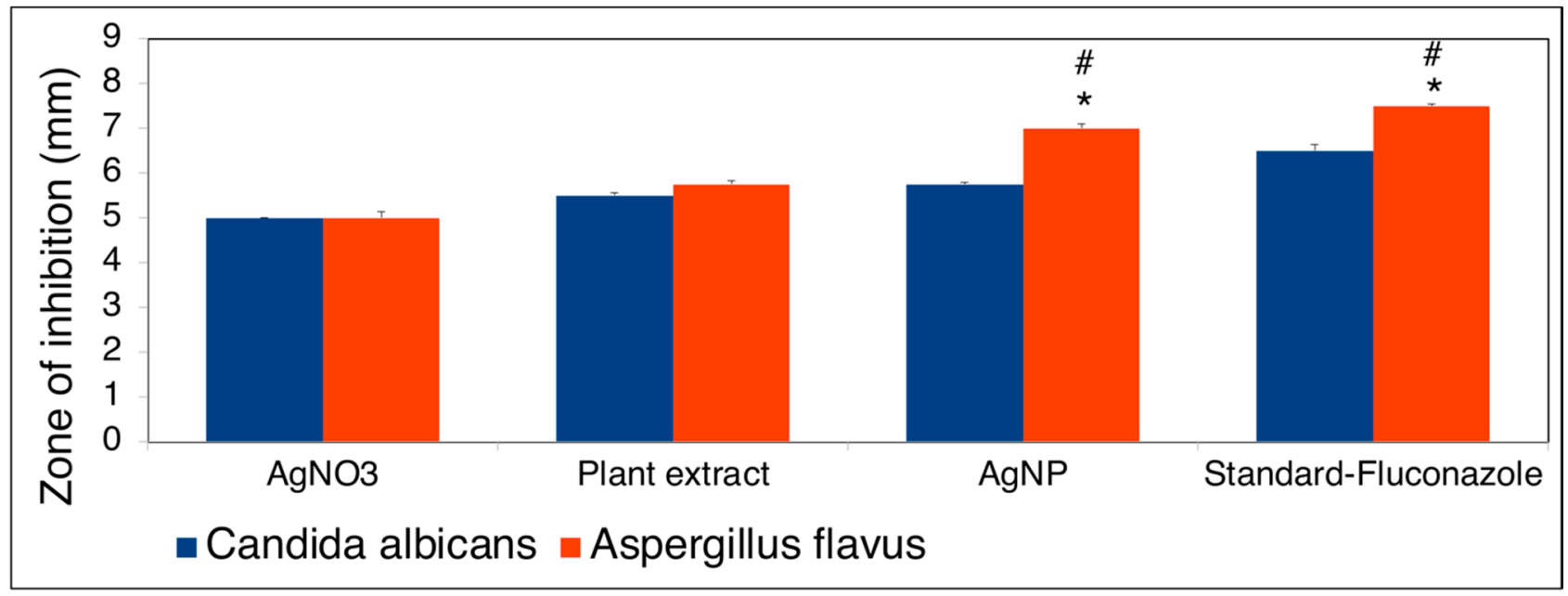

Figure 9. Quantitative antifungal strains (Aspergillus flavus (red) and Candida albicans (blue)) activity (measurements of zone inhibition activity) of biosynthesized Bauhinia tomentosa Linn flower-powder extract-derived AgNPs (as shown in Figure 8). Data are presented as mean \pm standard devation of four independent experiments $\left({ }^{*} p<0.01[A\right.$. flavus compared with $C$. albicans], \# $p<0.1$ [compared with $\mathrm{AgNO}_{3}$ and plant extract, respectively]).

\subsection{Antioxidant Activity of Biosynthesized AgNPs}

The radical scavenging activity of biosynthesized $B$. tomentosa Linn flower-powder extract-derived AgNPs was quantified spectrophotometrically by changing the DPPH color from brown to yellow. Inhibition of DPPH radical scavenging activity was found to be dose-dependent with half-maximal inhibitory concentration $\left(\mathrm{IC}_{50}\right)$ values of $56.77 \mu \mathrm{g} / \mathrm{mL}$ and $43.03 \mu \mathrm{g} / \mathrm{mL}$ for AgNPs and ascorbic acid (control), respectively (Figure 10).

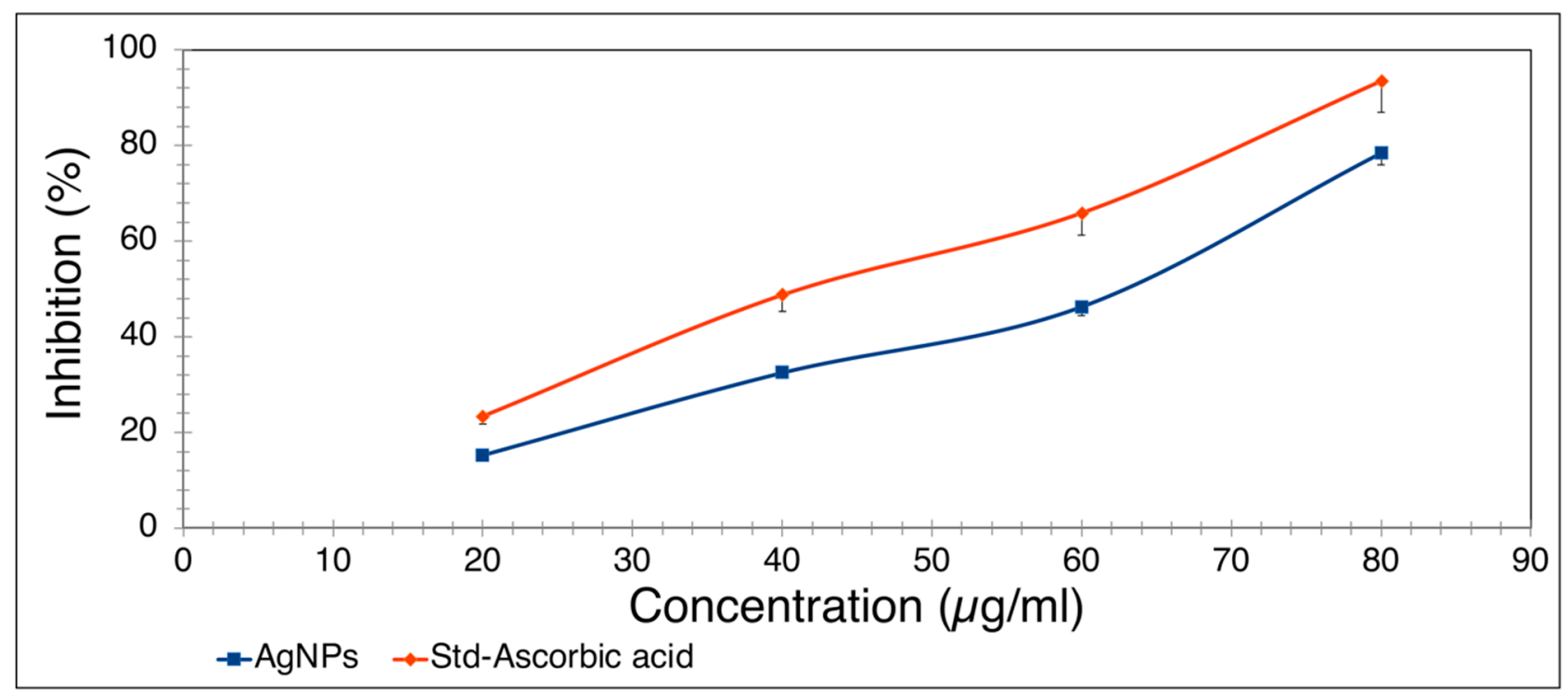

Figure 10. Dose-dependent antioxidant activity of biosynthesized Bauhinia tomentosa Linn flower-powder extract-derived AgNPs. Ascorbic acid served as a positive control. The indicated mean values are from two independent experiments performed in triplicate (maximum mean deviation $\pm 5 \%$ ).

\subsection{Molecular Docking of Biosynthesized AgNPs}

The antimicrobial mechanisms of AgNPs against bacterial or fungal pathogens remain unclear. AgNPs can directly attack and disrupt or penetrate cell walls to induce intracellular redox reactions mediating cytotoxicity. Moreover, AgNPs can interact with pivotal microbial proteins to inhibit their activities and cause cell death [78-81]. Accordingly, we 
selected representative proteins for each species to study the possible three-dimensional (3D) interaction of AgNPs with bacterial DNA gyrase [82,83], fungal CYP51 (cytochrome P450 monooxygenase (CYP) superfamily) [51,84] and fungal dihydrofolate reductase [85]. To predict the biological interactions of the biosynthesized $B$. tomentosa Linn flower-powder extract-derived AgNPs with these possible microbial target proteins, we performed molecular docking analysis using a Patch dock server for the 3D structures of PDB proteins 3G7B (DNA gyrase, S. aureus), 4WUB (DNA gyrase, E. coli), 5TZI (cytochrome P450, C. albicans), and 6DRS (dihydrofolate reductase, A. flavus). Silver nanoparticle bound microbe structures (DNA gyrase, cytochrome P450, and dihydrofolate reductase) were visualized for interaction by PyMOL (Version 2.3.0, PyMol Molecular Graphics system, Schrödinger, LLC, New York, NY, USA). By the molecular rendering approach, interaction of AgNPs with amino acid (AAs) in the target protein structures was identified. The AA residues interacted with silver through hydrophobic contact (Figure 11).

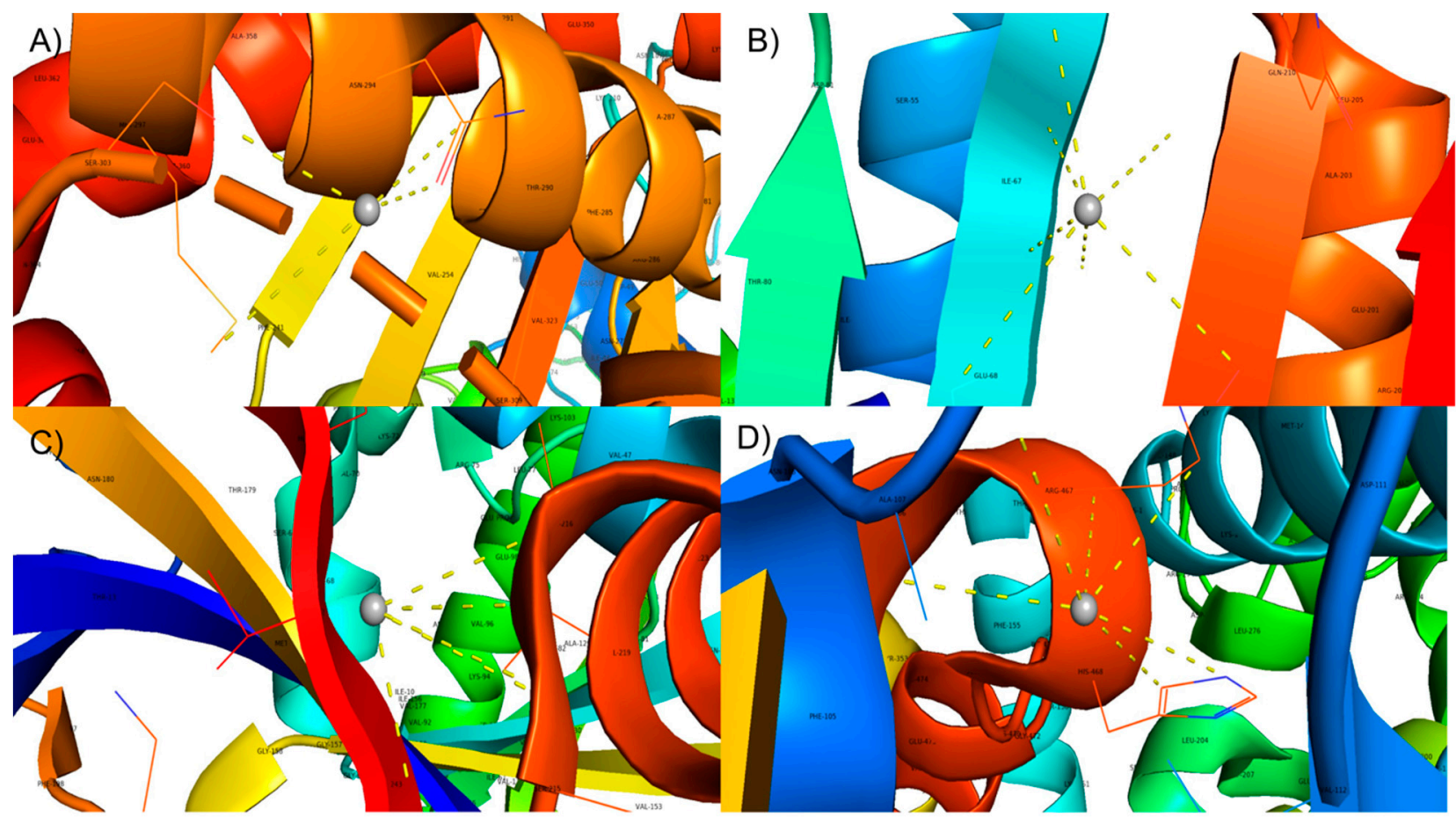

Figure 11. Molecular docking of AgNPs determines the binding ability of silver with various bacterial and fungal proteins. A 3D structure modeling of the interaction of silver (gray ball in the center of each subdisplay (A-D)) with bacterial species: (A) Staphylococcus aureus, (B) Escherichia coli; and with fungal species: (C) Candida albicans, (D) Aspergillus flavus. AgNP interactions with microbes were achieved by hydrophobic contact. PDB IDs used included 3G7B (DNA gyrase, Staphylococcus aureus), 4WUB (DNA gyrase, Escherichia coli), 5TZI (cytochrome P450, Candida albicans), and 6DRS (dihydrofolate reductase, Aspergillus flavus).

\section{Discussion}

We biosynthesized AgNPs using the natural extract of B. tomentosa Linn. We then applied various biophysical and biochemical methods to characterize the potential biomedical applications of the AgNPs [8-10,12-16,86] and validated their antimicrobial and antioxidant properties $[87,88]$. We also evaluated a possible mechanism of action via molecular docking analysis.

We applied multiple biophysical and biochemical methods to characterize our biosynthesized AgNPs. A UV-vis spectroscopic analysis showed a characteristic absorbance peak shift from $400 \mathrm{~nm}$ to $420 \mathrm{~nm}$ during the formation of biosynthesized B. tomentosa Linn flower-powder extract-derived AgNPs (Figure 1), which can be attributed to the formation of larger particles $[57,89,90]$. An EDX analysis helped demonstrate the elemental 
composition of the biosynthesized B. tomentosa Linn flower-powder extract-derived AgNPs (Figure 3, Table 2). The dense peak corresponding with silver strongly confirmed the reduction of $\mathrm{AgNO}_{3}$ and the formation of AgNPs. An EDX analysis also proved that the required phase of silver was present in the biosynthesized AgNPs [27,61,63,76,91]. The crystalline nature of the biosynthesized AgNPs was confirmed in the form of XRD diffraction peaks at $2 \theta=37^{\circ}, 49^{\circ}, 63^{\circ}$, and $76^{\circ}$ (corresponding to the planes of silver $111,200,220,311$ ), respectively (Figure 4), which are typical XRD values of biosynthesized AgNPs [65,76,92-94]. Additionally, FTIR spectroscopy confirmed the various functional (amine, alkyl, ether, and aliphatic) groups and chemical bonding of biosynthesized AgNPs, while SEM analysis revealed the surface morphology and size of the AgNPs, which assumed spherical, uniform shapes (Figure 5) [11,61,62].

To determine possible biomedical applications of the biosynthesized B. tomentosa Linn flower-powder extract-derived AgNPs we examined their potential antimicrobial activity. The biosynthesized AgNPs exhibited efficient anti-Gram-negative and anti-Grampositive bacterial activity, with higher efficiency against Gram-positive bacterial pathogens (Figures 6 and 7). Moreover, the biosynthesized AgNPs exhibited significant antifungal activity, as determined by the disk diffusion method, against $A$. flavus and C. albicans, respectively (Figures 8 and 9). Recent data point to the possible redox-potential of $B$. tomentosa Linn-derived AgNPs and their possible uses as antimicrobial agents [67]. The antimicrobial activity of our biosynthesized AgNPs may be mediated by a redox reaction, which was confirmed by the reduction and radical scavenging potential of silver in green biosynthesized AgNPs (against DPPH). The lowest concentration of the biosynthesized $B$. tomentosa Linn flower-powder extract-derived AgNPs was $20 \mu \mathrm{g} / \mathrm{mL}$, with an effectivity of $15.30 \pm 0.40 \%$ and an $\mathrm{IC}_{50}$ of 56.77 (Figure 10), which was superior and in the range of previously described AgNPs using other green sources $[63,95,96]$. Therefore, our results presented here indicate that our biogenic AgNPs are superior to other biosynthesized AgNPs in terms of higher in vitro antioxidant $[34,47,95]$ and higher in vitro antimicrobial efficacy (Table 3) $[34,45,47,56-58,61-63,65,69,70,96]$.

Table 3. Comparative antimicrobial efficacy of biosynthesized B. tomentosa Linn flower-powder extract-derived ${ }^{\$}$ AgNPs.

\begin{tabular}{|c|c|c|c|c|c|c|c|}
\hline & $\begin{array}{c}\text { Antioxidant } \\
\text { Efficacy, AgNPs } \$ \\
\text { IC }_{50} \\
\text { (AgNPs \& } \\
\text { Ascorbic Acid } \\
\text { (Control), } \\
\text { Respectively) } \\
\text { [ } \mu \mathrm{g} / \mathrm{mL}]\end{array}$ & 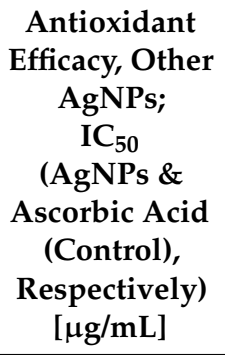 & $\begin{array}{c}\text { Antimicrobial } \\
\text { (Antibacterial) } \\
\text { Efficacy, } \\
\text { AgNPs } \$ \\
\text { Zone } \\
\text { Inhibition } \\
\text { [mm] }\end{array}$ & $\begin{array}{c}\text { Antimicrobial } \\
\text { (Antibacterial) } \\
\text { Efficacy, Other } \\
\text { AgNPs; } \\
\text { Zone } \\
\text { Inhibition } \\
\text { [mm] }\end{array}$ & $\begin{array}{c}\text { Antimicrobial } \\
\text { (Antifungal) } \\
\text { Efficacy, } \\
\text { AgNPs } \$ \\
\text { Zone } \\
\text { Inhibition } \\
\text { [mm] }\end{array}$ & $\begin{array}{l}\text { Antimicrobial } \\
\text { (Antifungal) } \\
\text { Efficacy, Other } \\
\text { AgNPs; } \\
\text { Zone } \\
\text { Inhibition } \\
\text { [mm] }\end{array}$ & References \\
\hline 1 & $56.77 \& 43.03$ & $50.37 \& 44.10$ & & & & & {$[47,63]$} \\
\hline 2 & & $46.25 \& 41.86$ & & & & & [95] \\
\hline 3 & & & $\begin{array}{c}6.75 \\
(\text { E. coli })(30 \mu \mathrm{L})\end{array}$ & $\begin{array}{c}11.4 \\
(\text { E. coli) }(50 \mu \mathrm{L})\end{array}$ & & & {$[57,67]$} \\
\hline 4 & & & $\begin{array}{c}9.25 \\
\text { (S. aureus) } \\
(30 \mu \mathrm{L})\end{array}$ & $\begin{array}{c}12.7 \\
\text { (S. aureus) } \\
(50 \mu \mathrm{L})\end{array}$ & & & {$[56,67]$} \\
\hline 5 & & & & & $\begin{array}{c}5.75 \\
\text { (C. albicans) } \\
(30 \mu \mathrm{L})\end{array}$ & $\begin{array}{c}10.7 \\
\text { (C. albicans) } \\
(50 \mu \mathrm{L})\end{array}$ & {$[39,97,98]$} \\
\hline 6 & & & & & $\begin{array}{c}7 \\
\text { (A. Flavus) } \\
(30 \mu \mathrm{L})\end{array}$ & $\begin{array}{c}20 \\
\text { (A. Flavus) } \\
(50 \mu \mathrm{L})\end{array}$ & {$[97,98]$} \\
\hline
\end{tabular}


Finally, we used molecular modeling and docking analyses to investigate the antibacterial and antifungal mode of action of the biosynthesized AgNPs. We observed AgNP-mediated cytotoxicity and identified the AA residues SER-303, ASN-294 (DNA gyrase from Escherichia coli), ILE-67, THR-212, GLN-210 (DNA gyrase from S. aureus), ALA107, PHE-105 (cytochrome P450 from C. albicans), and VAL-214, ALA-216 (dihydrofolate reductase from $A$. flavus) as possible participants in hydrophobic interactions with validated silver in the biosynthesized AgNPs, which are potentially responsible for the antibacterial and antifungal redox reactions mediating microbial cytotoxicity. We inferred from molecular modeling and docking studies that the biosynthesized AgNPs can effectively bind to microbes and act as antimicrobial agents (Figure 11) [66,70,99].

Thus, the use of B. tomentosa Linn extracts for the synthesis of biomedically important AgNPs therefore has several advantages, since the environmentally friendly synthesis provides stable and highly effective AgNPs with a highly effective redox potential for highly effective antimicrobial activity and possible biomedical applications (Figure 12) [7,34,41,43-47].

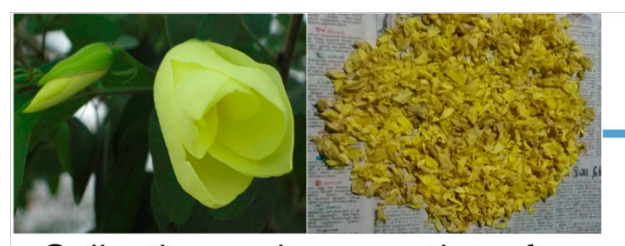

Collection and preparation of B. tomentosa Linn. flower

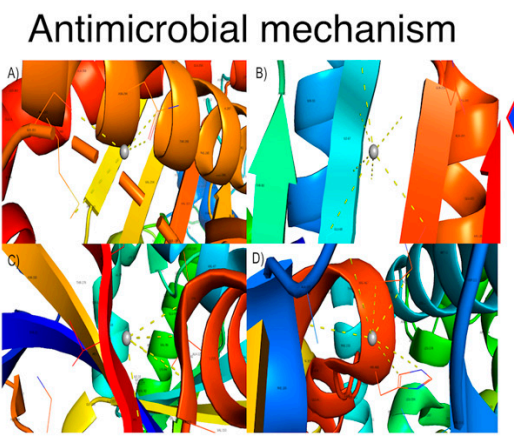

AgNPs could inhibit DNA gyrase, cytochrome P450 and dehydrofolate reductase

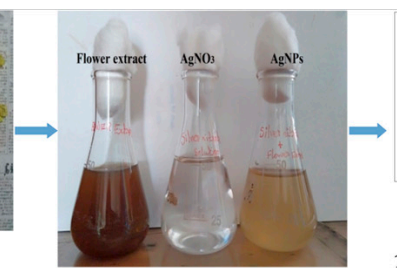

Synthesis of AgNPs (brown to yellow)

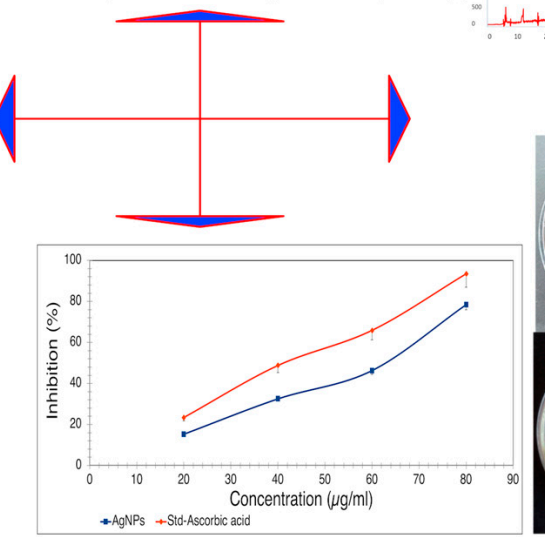

Antioxidant properties

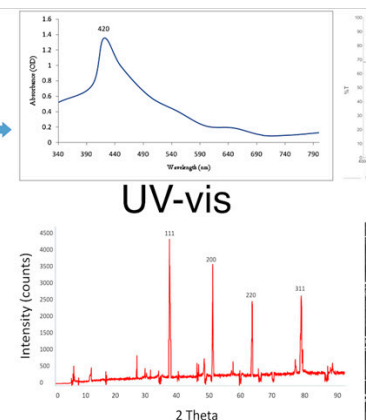

XRD

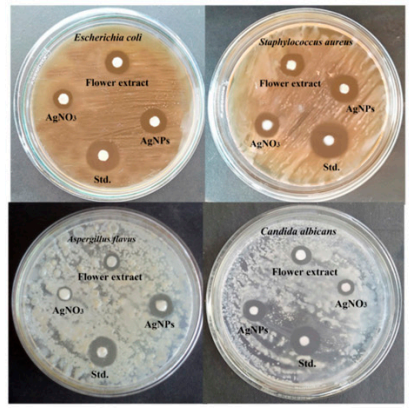

Antimicrobial properties

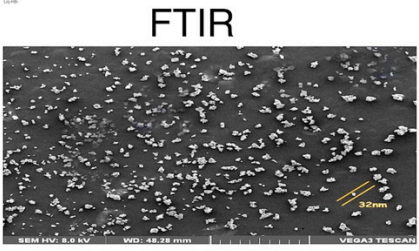

SEM
E. coli (G-)

$\&$

S. aureus $\left(\mathrm{G}^{+}\right)$

A. flavus

\&

C. albicans

Figure 12. Overview of the study of B. tomentosa Linn flower extract-derived biogenic AgNPs. Biosynthesized AgNPs (change in the color (brown to yellow) of the solution over time when aqueous plant extract was added to a $\mathrm{AgNO}_{3}$ solution). Biophysical characterization of biosynthesized AgNPs by UV-vis, FTIR, XRD, and SEM confirmed the nature of AgNPs. Biochemical and cellular analyses confirmed the antioxidant (dose-dependent DPPH radical scavenging activity) and antimicrobial (antibacterial (Gram-positive $\left(\mathrm{G}^{+}\right)$and Gram-negative $\left(\mathrm{G}^{-}\right)$) and antifungal) properties of the biogenic AgNPs. Molecular modelling and docking studies indicated the possible antimicrobial activity mechanism of the biogenic AgNPs: inhibition of key enzymes such as DNA gyrase, cytochrome P450, and dihydrofolate reductase.

\section{Conclusions}

Silver nanoparticles from different natural sources are useful industrial and medicinal tools. B. tomentosa Linn flower-powder extract-derived AgNPs were characterized through $\mathrm{UV}$-vis spectrophotometry, FTIR, XRD, and EDX. We observed the reduction of $\mathrm{Ag}^{+}$to $\mathrm{Ag}^{0}$ with an accompanied UV-vis spectral peak shift from $400 \mathrm{~nm}$ to $420 \mathrm{~nm}$ over $4 \mathrm{~h}$. The FTIR analysis revealed the functional (amine, alkyl, ether, and aliphatic) groups of AgNPs, while XRD analysis showed that the biosynthesized AgNPs had a crystalline structure. Results of SEM analysis revealed the AgNPs were spheres approximately $32 \mathrm{~nm}$ in diameter. 
The results of EDX examination confirmed the presence of $\mathrm{Ag}^{0}$ in biosynthesized AgNPs with reducing antioxidant properties validated by DPPH assays. Biologically synthesized AgNPs exhibited antibacterial activity against E. coli (Gram-negative) and S. aureus (Grampositive) as well as antifungal activity against $C$. albicans and A. flavus. A possible mode of reducing antibacterial and antifungal activities was studied by molecular docking analysis, which indicated that the biosynthesized $B$. tomentos $a$ Linn flower-powder extract-derived AgNPs may be able to inhibit key enzymes, such as bacterial DNA gyrase and fungal cytochrome P450 (C. albicans) and dihydrofolate reductase (A. flavus). This study may pave the way for the development of new and potentially antimicrobial compounds based on biosynthesized B. tomentosa Linn flower-powder extract-derived AgNPs (Figure 12).

Author Contributions: Conceptualization, S.R. and K.H.; methodology, S.R., S.S., N.K. and P.V.; validation, S.R., K.H., P.-S.K. and A.K.; formal analysis, S.R., S.S., N.K., P.V. and K.H.; investigation, S.R., S.S., N.K., P.V. and K.H.; resources, S.R. and K.H.; data curation, S.R. and K.H.; writing-original draft preparation, S.R. and K.H.; writing-review and editing, A.K., P.-S.K. and K.H.; visualization, S.R., P.-S.K. and A.K.; supervision, S.R. and K.H.; project administration, S.R. and K.H.; funding acquisition, S.R., A.K., P.-S.K. and K.H. All authors have read and agreed to the published version of the manuscript.

Funding: This research received no external funding.

Institutional Review Board Statement: Not applicable.

Informed Consent Statement: Not applicable.

Data Availability Statement: Data is contained within the article.

Conflicts of Interest: The authors have no competing financial interests.

\section{References}

1. Prestinaci, F.; Pezzotti, P.; Pantosti, A. Antimicrobial resistance: A global multifaceted phenomenon. Pathog. Glob. Health 2015, 109, 309-318. [CrossRef] [PubMed]

2. Morehead, M.S.; Scarbrough, C. Emergence of global antibiotic resistance. Prim. Care 2018, 45, 467-484. [CrossRef]

3. Loo, Y.Y.; Rukayadi, Y.; Nor-Khaizura, M.A.; Kuan, C.H.; Chieng, B.W.; Nishibuchi, M.; Radu, S. In vitro antimicrobial activity of green synthesized silver nanoparticles against selected gram-negative foodborne pathogens. Front. Microbiol. $2018,9,1555$. [CrossRef] [PubMed]

4. Dakal, T.C.; Kumar, A.; Majumdar, R.S.; Yadav, V. Mechanistic basis of antimicrobial actions of silver nanoparticles. Front. Microbiol. 2016, 7, 1831. [CrossRef] [PubMed]

5. Mare, A.D.; Ciurea, C.N.; Man, A.; Mares, M.; Toma, F.; Berța, L.; Tanase, C. In vitro antifungal activity of silver nanoparticles biosynthesized with beech bark extract. Plants 2021, 10, 2153. [CrossRef]

6. Galúcio, J.M.P.; de Souza, S.G.B.; Vasconcelos, A.A.; Lima, A.K.O.; da Costa, K.S.; de Campos Braga, H.; Taube, P.S. Synthesis, characterization, applications, and toxicity of green synthesized nanoparticles. Curr. Pharm. Biotechnol. 2021, 22. [CrossRef] [PubMed]

7. Formoso, P.; Muzzalupo, R.; Tavano, L.; De Filpo, G.; Nicoletta, F.P. Nanotechnology for the environment and medicine. Mini Rev. Med. Chem. 2016, 16, 668-675. [CrossRef]

8. Almatroudi, A. Silver nanoparticles: Synthesis, characterisation and biomedical applications. Open Life Sci. 2020, 15, 819-839. [CrossRef] [PubMed]

9. Lee, S.H.; Jun, B.H. Silver nanoparticles: Synthesis and application for nanomedicine. Int. J. Mol. Sci. 2019, 20, 865. [CrossRef]

10. Shanmuganathan, R.; Karuppusamy, I.; Saravanan, M.; Muthukumar, H.; Ponnuchamy, K.; Ramkumar, V.S.; Pugazhendhi, A. Synthesis of silver nanoparticles and their biomedical applications-A comprehensive review. Curr. Pharm. Des. 2019, 25, 2650-2660. [CrossRef] [PubMed]

11. Zhang, X.F.; Liu, Z.G.; Shen, W.; Gurunathan, S. Silver nanoparticles: Synthesis, characterization, properties, applications, and therapeutic approaches. Int. J. Mol. Sci. 2016, 17, 1534. [CrossRef] [PubMed]

12. Robinson, J.R.; Isikhuemhen, O.S.; Anike, F.N. Fungal-metal interactions: A review of toxicity and homeostasis. J. Fungi 2021, 7, 225. [CrossRef] [PubMed]

13. Wahab, S.; Khan, T.; Adil, M.; Khan, A. Mechanistic aspects of plant-based silver nanoparticles against multi-drug resistant bacteria. Heliyon 2021, 7, e07448. [CrossRef]

14. Bruna, T.; Maldonado-Bravo, F.; Jara, P.; Caro, N. Silver nanoparticles and their antibacterial applications. Int. J. Mol. Sci. 2021, 22, 7202. [CrossRef] [PubMed] 
15. Tortella, G.; Rubilar, O.; Fincheira, P.; Pieretti, J.C.; Duran, P.; Lourenço, I.M.; Seabra, A.B. Bactericidal and virucidal activities of biogenic metal-based nanoparticles: Advances and perspectives. Antibiotics 2021, 10, 783. [CrossRef]

16. Tortella, G.R.; Pieretti, J.C.; Rubilar, O.; Fernández-Baldo, M.; Benavides-Mendoza, A.; Diez, M.C.; Seabra, A.B. Silver, copper and copper oxide nanoparticles in the fight against human viruses: Progress and perspectives. Crit. Rev. Biotechnol. 2021, 1-19. [CrossRef]

17. Kelkawi, A.H.A.; Abbasi Kajani, A.; Bordbar, A.K. Green synthesis of silver nanoparticles using Mentha pulegium and investigation of their antibacterial, antifungal and anticancer activity. IET Nanobiotechnol. 2017, 11, 370-376. [CrossRef]

18. Curulli, A. Nanomaterials in electrochemical sensing area: Applications and challenges in food analysis. Molecules 2020, 25, 5759. [CrossRef]

19. Sainio, S.; Leppänen, E.; Mynttinen, E.; Palomäki, T.; Wester, N.; Etula, J.; Isoaho, N.; Peltola, E.; Koehne, J.; Meyyappan, M.; et al Integrating carbon nanomaterials with metals for bio-sensing applications. Mol. Neurobiol. 2020, 57, 179-190. [CrossRef]

20. Poulose, S.; Panda, T.; Nair, P.P.; Théodore, T. Biosynthesis of silver nanoparticles. J. Nanosci. Nanotechnol. 2014, 14, 2038-2049. [CrossRef] [PubMed]

21. Sachin, K.; Karn, S.K. Microbial fabricated nanosystems: Applications in drug delivery and targeting. Front. Chem. 2021, 9, 617353. [CrossRef]

22. Gomes, H.I.O.; Martins, C.S.M.; Prior, J.A.V. Silver nanoparticles as carriers of anticancer drugs for efficient target treatment of cancer cells. Nanomaterials 2021, 11, 964. [CrossRef]

23. Slavin, Y.N.; Asnis, J.; Häfeli, U.O.; Bach, H. Metal nanoparticles: Understanding the mechanisms behind antibacterial activity. J. Nanobiotechnol. 2017, 15, 65. [CrossRef]

24. Hu, D.; Gu, X.; Si, W.; Qin, W.; Jiao, J.; Hao, Y. Biosynthesis of silver nanoparticles using Bauhinia acuminate flower extract and their effect to promote osteogenesis of MSCs and improve meniscus injury healing. J. Photochem. Photobiol. B 2019, 197, 111536. [CrossRef]

25. Morais, M.; Teixeira, A.L.; Dias, F.; Machado, V.; Medeiros, R.; Prior, J.A.V. Cytotoxic effect of silver nanoparticles synthesized by green methods in cancer. J. Med. Chem. 2020, 63, 14308-14335. [CrossRef] [PubMed]

26. Ruiz-Pulido, G.; Medina, D.I.; Barani, M.; Rahdar, A.; Sargazi, G.; Baino, F.; Pandey, S. Nanomaterials for the diagnosis and treatment of head and neck cancers: A review. Materials 2021, 14, 3706. [CrossRef]

27. Saha, P.; Mahiuddin, M.; Islam, A.; Ochiai, B. Biogenic synthesis and catalytic efficacy of silver nanoparticles based on peel extracts of citrus macroptera fruit. ACS Omega 2021, 6, 18260-18268. [CrossRef]

28. Li, P.J.; Pan, J.J.; Tao, L.J.; Li, X.; Su, D.L.; Shan, Y.; Li, H.Y. Green synthesis of silver nanoparticles by extracellular extracts from aspergillus japonicus pj01. Molecules 2021, 26, 4479. [CrossRef]

29. Santos, T.S.; Silva, T.M.; Cardoso, J.C.; Albuquerque-Júnior, R.L.C.; Zielinska, A.; Souto, E.B.; Severino, P.; Mendonça, M.D.C. Biosynthesis of silver nanoparticles mediated by entomopathogenic fungi: Antimicrobial resistance, nanopesticides, and toxicity. Antibiotics 2021, 10, 852. [CrossRef]

30. Maghimaa, M.; Alharbi, S.A. Green synthesis of silver nanoparticles from Curcuma longa L. and coating on the cotton fabrics for antimicrobial applications and wound healing activity. J. Photochem. Photobiol. B 2020, 204, 111806. [CrossRef] [PubMed]

31. Lagashetty, A.; Ganiger, S.K.; Shashidhar. Synthesis, characterization and antibacterial study of Ag-Au bi-metallic nanocomposite by bioreduction using piper betle leaf extract. Heliyon 2019, 5, e02794. [CrossRef]

32. Gholami, M.; Shahzamani, K.; Marzban, A.; Lashgarian, H.E. Evaluation of antimicrobial activity of synthesised silver nanoparticles using Thymus kotschyanus aqueous extract. IET Nanobiotechnol. 2018, 12, 1114-1117. [CrossRef]

33. Khalilzadeh, M.A.; Borzoo, M. Green synthesis of silver nanoparticles using onion extract and their application for the preparation of a modified electrode for determination of ascorbic acid. J. Food Drug Anal. 2016, 24, 796-803. [CrossRef]

34. Keshari, A.K.; Srivastava, R.; Singh, P.; Yadav, V.B.; Nath, G. Antioxidant and antibacterial activity of silver nanoparticles synthesized by Cestrum nocturnum. J. Ayurveda Integr. Med. 2020, 11, 37-44. [CrossRef]

35. Kannan, N.; Renitta, R.E.; Guruvayoorappan, C. Bauhinia tomentosa stimulates the immune system and scavenges free radical generation in vitro. J. Basic Clin. Physiol. Pharmacol. 2010, 21, 157-168. [CrossRef]

36. Kannan, N.; Guruvayoorappan, C. Protective effect of Bauhinia tomentosa on acetic acid induced ulcerative colitis by regulating antioxidant and inflammatory mediators. Int. Immunopharmacol. 2013, 16, 57-66. [CrossRef]

37. Kannan, N.; Sakthivel, K.M.; Guruvayoorappan, C. Anti-tumor and chemoprotective effect of bauhinia tomentosa by regulating growth factors and inflammatory mediators. Asian Pac. J. Cancer Prev. 2015, 16, 8119-8126. [CrossRef]

38. Devaki, K.; Beulah, U.; Akila, G.; Narmadha, R.; Gopalakrishnan, V.K. Glucose lowering effect of aqueous extract of Bauhinia tomentosa L. on alloxan induced type 2 diabetes mellitus in wistar albino rats. J. Basic Clin. Pharm. 2011, 2, 167-174. [PubMed]

39. Dugasani, S.; Balijepalli, M.K.; Tandra, S.; Pichika, M.R. Antimicrobial activity of Bauhinia tomentosa and Bauhinia vahlii roots. Pharmacogn. Mag. 2010, 6, 204-207. [CrossRef]

40. Radha, R.; Vasantha, V.S.; Pitchumani, K. Chemical constituents from the flowering buds of Bauhinia tomentosa Linn (FBBT). Nat. Prod. Res. 2016, 30, 1670-1674. [CrossRef] [PubMed]

41. Lakshminarayanan, S.; Shereen, M.F.; Niraimathi, K.L.; Brindha, P.; Arumugam, A. One-pot green synthesis of iron oxide nanoparticles from Bauhinia tomentosa: Characterization and application towards synthesis of 1, 3 diolein. Sci. Rep. 2021, 11, 8643. [CrossRef] 
42. Cechinel Filho, V. Chemical composition and biological potential of plants from the genus Bauhinia. Phytother. Res. 2009, 23, 1347-1354. [CrossRef]

43. Singh, H.; Du, J.; Singh, P.; Yi, T.H. Ecofriendly synthesis of silver and gold nanoparticles by Euphrasia officinalis leaf extract and its biomedical applications. Artif. Cells Nanomed. Biotechnol. 2018, 46, 1163-1170. [CrossRef]

44. Li, Z.; Ali, I.; Qiu, J.; Zhao, H.; Ma, W.; Bai, A.; Wang, D.; Li, J. Eco-friendly and facile synthesis of antioxidant, antibacterial and anticancer dihydromyricetin-mediated silver nanoparticles. Int. J. Nanomed. 2021, 16, 481-492. [CrossRef] [PubMed]

45. Singh, P.; Pandit, S.; Jers, C.; Joshi, A.S.; Garnæs, J.; Mijakovic, I. Silver nanoparticles produced from Cedecea sp. exhibit antibiofilm activity and remarkable stability. Sci. Rep. 2021, 11, 12619. [CrossRef]

46. Ghosh, S.; Ahmad, R.; Zeyaullah, M.; Khare, S.K. Microbial nano-factories: Synthesis and biomedical applications. Front. Chem. 2021, 9, 626834. [CrossRef]

47. Ansar, S.; Tabassum, H.; Aladwan, N.S.M.; Naiman Ali, M.; Almaarik, B.; AlMahrouqi, S.; Abudawood, M.; Banu, N.; Alsubki, R. Eco friendly silver nanoparticles synthesis by Brassica oleracea and its antibacterial, anticancer and antioxidant properties. Sci. Rep. 2020, 10, 18564. [CrossRef]

48. Khan, T.; Sankhe, K.; Suvarna, V.; Sherje, A.; Patel, K.; Dravyakar, B. DNA gyrase inhibitors: Progress and synthesis of potent compounds as antibacterial agents. Biomed. Pharmacother. 2018, 103, 923-938. [CrossRef]

49. Lah, L.; Podobnik, B.; Novak, M.; Korošec, B.; Berne, S.; Vogelsang, M.; Kraševec, N.; Zupanec, N.; Stojan, J.; Bohlmann, J.; et al. The versatility of the fungal cytochrome P450 monooxygenase system is instrumental in xenobiotic detoxification. Mol. Microbiol. 2011, 81, 1374-1389. [CrossRef]

50. Gupta, P.; Verma, R.; Verma, A.K.; Chattopadhyay, P.C. A versatile tool in controlling aggregation and Ag nanoparticles assisted in vitro folding of thermally denatured zDHFR. Biochem. Biophys. Rep. 2020, 24, 100856. [CrossRef]

51. Hargrove, T.Y.; Friggeri, L.; Wawrzak, Z.; Qi, A.; Hoekstra, W.J.; Schotzinger, R.J.; York, J.D.; Guengerich, F.P.; Lepesheva, G.I. Structural analyses of Candida albicans sterol $14 \alpha$-demethylase complexed with azole drugs address the molecular basis of azole-mediated inhibition of fungal sterol biosynthesis. J. Biol. Chem. 2017, 292, 6728-6743. [CrossRef]

52. Mishra, M.; Huang, J.; Lee, Y.Y.; Chua, D.S.; Lin, X.; Hu, J.M.; Heese, K. Gastrodia elata modulates amyloid precursor protein cleavage and cognitive functions in mice. Biosci. Trends 2011, 5, 129-138. [CrossRef] [PubMed]

53. Feng, L.; Manavalan, A.; Mishra, M.; Sze, S.K.; Hu, J.M.; Heese, K. Tianma modulates blood vessel tonicity. Open Biochem. J. 2012, 6, 56-65. [CrossRef]

54. Renganathan, S.; Manokaran, S.; Vasanthakumar, P.; Singaravelu, U.; Kim, P.S.; Kutzner, A.; Heese, K. Phytochemical profiling in conjunction with in vitro and in silico studies to identify human $\alpha$-amylase inhibitors in Leucaena leucocephala (Lam.) De Wit for the treatment of diabetes mellitus. ACS Omega 2021, 6, 19045-19057. [CrossRef]

55. Harborne, A.J. Phytochemical Methods A Guide to Modern Techniques of Plant. Analysis, 3rd ed.; Chapman \& Hall: London, UK, 1998.

56. Ashraf, A.; Zafar, S.; Zahid, K.; Salahuddin Shah, M.; Al-Ghanim, K.A.; Al-Misned, F.; Mahboob, S. Synthesis, characterization, and antibacterial potential of silver nanoparticles synthesized from Coriandrum sativum L. J. Infect. Public Health 2019, 12, $275-281$. [CrossRef]

57. Kgatshe, M.; Aremu, O.S.; Katata-Seru, L.; Gopane, R. Characterization and antibacterial activity of biosynthesized silver nanoparticles using the ethanolic extract of Pelargonium sidoides DC. J. Nanomater. 2019, 2019, 3501234. [CrossRef]

58. Bernardo-Mazariegos, E.; Valdez-Salas, B.; González-Mendoza, D.; Abdelmoteleb, A.; Tzintzun Camacho, O.; Ceceña Duran, C.; Gutiérrez-Miceli, F. Silver nanoparticles from Justicia spicigera and their antimicrobial potentialities in the biocontrol of foodborne bacteria and phytopathogenic fungi. Rev. Argent. Microbiol. 2019, 51, 103-109. [CrossRef]

59. Ashraf, J.M.; Ansari, M.A.; Khan, H.M.; Alzohairy, M.A.; Choi, I. Green synthesis of silver nanoparticles and characterization of their inhibitory effects on AGEs formation using biophysical techniques. Sci. Rep. 2016, 6, 20414. [CrossRef] [PubMed]

60. Nandiyanto, A.B.D.; Oktiani, R.; Ragadhita, R. How to read and interpret FTIR spectroscope of organic material. Indones. J. Sci. Technol. 2019, 4, 97-118. [CrossRef]

61. Shehzad, A.; Qureshi, M.; Jabeen, S.; Ahmad, R.; Alabdalall, A.H.; Aljafary, M.A.; Al-Suhaimi, E. Synthesis, characterization and antibacterial activity of silver nanoparticles using Rhazya stricta. PeerJ 2018, 6, e6086. [CrossRef]

62. Goudarzi, M.; Mir, N.; Mousavi-Kamazani, M.; Bagheri, S.; Salavati-Niasari, M. Biosynthesis and characterization of silver nanoparticles prepared from two novel natural precursors by facile thermal decomposition methods. Sci. Rep. 2016, 6, 32539. [CrossRef]

63. Abbai, R.; Mathiyalagan, R.; Markus, J.; Kim, Y.J.; Wang, C.; Singh, P.; Ahn, S.; Farh Mel, A.; Yang, D.C. Green synthesis of multifunctional silver and gold nanoparticles from the oriental herbal adaptogen: Siberian ginseng. Int. J. Nanomed. 2016, 11, 3131-3143. [CrossRef]

64. Bunaciu, A.A.; Udriştioiu, E.G.; Aboul-Enein, H.Y. X-ray diffraction: Instrumentation and applications. Crit. Rev. Anal. Chem. 2015, 45, 289-299. [CrossRef] [PubMed]

65. Nayak, D.; Ashe, S.; Rauta, P.R.; Nayak, B. Biosynthesis, characterisation and antimicrobial activity of silver nanoparticles using Hibiscus rosa-sinensis petals extracts. IET Nanobiotechnol. 2015, 9, 288-293. [CrossRef] [PubMed]

66. Karthik, C.S.; Manukumar, H.M.; Ananda, A.P.; Nagashree, S.; Rakesh, K.P.; Mallesha, L.; Qin, H.L.; Umesha, S.; Mallu, P.; Krishnamurthy, N.B. Synthesis of novel benzodioxane midst piperazine moiety decorated chitosan silver nanoparticle against biohazard pathogens and as potential anti-inflammatory candidate: A molecular docking studies. Int. J. Biol. Macromol. 2018, 108, 489-502. [CrossRef] [PubMed] 
67. Ramar, K.; Vasanthakumar, V.; Priyadharsan, A.; Priya, P.; Raj, V.; Anbarasan, P.M.; Vasanthakumari, R.; Jafar Ahamed, A. Green synthetic approach of silver nanoparticles from Bauhinia tomentosa Linn. leaves extract for potent photocatalytic and in vitro biological applications. J. Mater. Sci. Mater. Electron. 2018, 29, 11509-11520. [CrossRef]

68. Pei, J.; Fu, B.; Jiang, L.; Sun, T. Biosynthesis, characterization, and anticancer effect of plant-mediated silver nanoparticles using Coptis chinensis. Int. J. Nanomed. 2019, 14, 1969-1978. [CrossRef] [PubMed]

69. Bocate, K.P.; Reis, G.F.; de Souza, P.C.; Oliveira Junior, A.G.; Durán, N.; Nakazato, G.; Furlaneto, M.C.; de Almeida, R.S.; Panagio, L.A. Antifungal activity of silver nanoparticles and simvastatin against toxigenic species of Aspergillus. Int. J. Food Microbiol. 2019, 291, 79-86. [CrossRef] [PubMed]

70. Hussain, A.; Alajmi, M.F.; Khan, M.A.; Pervez, S.A.; Ahmed, F.; Amir, S.; Husain, F.M.; Khan, M.S.; Shaik, G.M.; Hassan, I.; et al. Biosynthesized silver nanoparticle (AgNP) from Pandanus odorifer leaf extract exhibits anti-metastasis and anti-biofilm potentials. Front. Microbiol. 2019, 10, 8. [CrossRef]

71. Schneidman-Duhovny, D.; Inbar, Y.; Nussinov, R.; Wolfson, H.J. PatchDock and SymmDock: Servers for rigid and symmetric docking. Nucleic. Acids Res. 2005, 33, W363-W367. [CrossRef] [PubMed]

72. Pramanik, S.; Kutzner, A.; Heese, K. Lead discovery and in silico 3D structure modeling of tumorigenic FAM72A (p17). Tumour Biol. 2015, 36, 239-249. [CrossRef]

73. Pramanik, S.; Kutzner, A.; Heese, K. 3D structure, dimerization modeling, and lead discovery by ligand-protein interaction analysis of p60 transcription regulator protein (p60TRP). Mol. Inform. 2016, 35, 99-108. [CrossRef] [PubMed]

74. Pramanik, S.; Thaker, M.; Perumal, A.G.; Ekambaram, R.; Poondla, N.; Schmidt, M.; Kim, P.S.; Kutzner, A.; Heese, K. Proteomic atomics reveals a distinctive uracil-5-methyltransferase. Mol. Inform. 2020, 39, e1900135. [CrossRef]

75. Patil, M.P.; Singh, R.D.; Koli, P.B.; Patil, K.T.; Jagdale, B.S.; Tipare, A.R.; Kim, G.D. Antibacterial potential of silver nanoparticles synthesized using Madhuca longifolia flower extract as a green resource. Microb. Pathog. 2018, 121, 184-189. [CrossRef]

76. Wang, C.; Mathiyalagan, R.; Kim, Y.J.; Castro-Aceituno, V.; Singh, P.; Ahn, S.; Wang, D.; Yang, D.C. Rapid green synthesis of silver and gold nanoparticles using Dendropanax morbifera leaf extract and their anticancer activities. Int. J. Nanomed. 2016, 11, 3691-3701. [CrossRef]

77. Geethalakshmi, R.; Sarada, D.V. Gold and silver nanoparticles from Trianthema decandra: Synthesis, characterization, and antimicrobial properties. Int. J. Nanomed. 2012, 7, 5375-5384. [CrossRef]

78. Liao, C.; Li, Y.; Tjong, S.C. Bactericidal and Cytotoxic Properties of Silver Nanoparticles. Int. J. Mol. Sci. 2019, 20, 449. [CrossRef] [PubMed]

79. Khalandi, B.; Asadi, N.; Milani, M.; Davaran, S.; Abadi, A.J.; Abasi, E.; Akbarzadeh, A. A review on potential role of silver nanoparticles and possible mechanisms of their actions on bacteria. Drug Res. (Stuttg.) 2017, 67, 70-76. [CrossRef] [PubMed]

80. Balakumaran, M.D.; Ramachandran, R.; Balashanmugam, P.; Mukeshkumar, D.J.; Kalaichelvan, P.T. Mycosynthesis of silver and gold nanoparticles: Optimization, characterization and antimicrobial activity against human pathogens. Microbiol. Res. 2016, 182, 8-20. [CrossRef]

81. Durán, N.; Nakazato, G.; Seabra, A.B. Antimicrobial activity of biogenic silver nanoparticles, and silver chloride nanoparticles: An overview and comments. Appl. Microbiol. Biotechnol. 2016, 100, 6555-6570. [CrossRef] [PubMed]

82. Ronkin, S.M.; Badia, M.; Bellon, S.; Grillot, A.L.; Gross, C.H.; Grossman, T.H.; Mani, N.; Parsons, J.D.; Stamos, D.; Trudeau, M.; et al. Discovery of pyrazolthiazoles as novel and potent inhibitors of bacterial gyrase. Bioorg. Med. Chem. Lett. 2010, 20, $2828-2831$. [CrossRef]

83. Hearnshaw, S.J.; Chung, T.T.; Stevenson, C.E.; Maxwell, A.; Lawson, D.M. The role of monovalent cations in the ATPase reaction of DNA gyrase. Acta Crystallogr. D Biol. Crystallogr. 2015, 71, 996-1005. [CrossRef] [PubMed]

84. Zhang, J.; Li, L.; Lv, Q.; Yan, L.; Wang, Y.; Jiang, Y. The Fungal CYP51s: Their Functions, Structures, Related Drug Resistance, and Inhibitors. Front. Microbiol. 2019, 10, 691. [CrossRef] [PubMed]

85. DeJarnette, C.; Luna-Tapia, A.; Estredge, L.R.; Palmer, G.E. Dihydrofolate reductase is a valid target for antifungal development in the human pathogen candida albicans. mSphere 2020, 5, e00374-20. [CrossRef]

86. Kedi, P.B.E.; Meva, F.E.; Kotsedi, L.; Nguemfo, E.L.; Zangueu, C.B.; Ntoumba, A.A.; Mohamed, H.E.A.; Dongmo, A.B.; Maaza, M. Eco-friendly synthesis, characterization, in vitro and in vivo anti-inflammatory activity of silver nanoparticle-mediated Selaginella myosurus aqueous extract. Int. J. Nanomed. 2018, 13, 8537-8548. [CrossRef]

87. Akter, M.; Sikder, M.T.; Rahman, M.M.; Ullah, A.; Hossain, K.F.B.; Banik, S.; Hosokawa, T.; Saito, T.; Kurasaki, M. A systematic review on silver nanoparticles-induced cytotoxicity: Physicochemical properties and perspectives. J. Adv. Res. 2018, 9, 1-16. [CrossRef] [PubMed]

88. Al-Huqail, A.A.; Hatata, M.M.; Al-Huqail, A.A.; Ibrahim, M.M. Preparation, characterization of silver phyto nanoparticles and their impact on growth potential of Lupinus termis L. seedlings. Saudi J. Biol. Sci 2018, 25, 313-319. [CrossRef] [PubMed]

89. Chiguvare, H.; Oyedeji, O.O.; Matewu, R.; Aremu, O.; Oyemitan, I.A.; Oyedeji, A.O.; Nkeh-Chungag, B.N.; Songca, S.P.; Mohan, S.; Oluwafemi, O.S. Synthesis of silver nanoparticles using buchu plant extracts and their analgesic properties. Molecules 2016, 21, 774. [CrossRef] [PubMed]

90. Jadou, A.; Al-Shahwany, A.W. Biogenic Synthesis and Characterization of Silver Nanoparticles Using Some Medical Plants and Evaluation of Their Antibacterial and Toxicity Potential. J. AOAC Int. 2018, 101, 1905-1912. [CrossRef] 
91. Erdogan, O.; Abbak, M.; Demirbolat, G.M.; Birtekocak, F.; Aksel, M.; Pasa, S.; Cevik, O. Green synthesis of silver nanoparticles via Cynara scolymus leaf extracts: The characterization, anticancer potential with photodynamic therapy in MCF7 cells. PLoS ONE 2019, 14, e0216496. [CrossRef] [PubMed]

92. Shahriari Ahmadi, F.; Tanhaeian, A.; Habibi Pirkohi, M. Biosynthesis of silver nanoparticles using chlamydomonas reinhardtii and its inhibitory effect on growth and virulence of listeria monocytogenes. Iran. J. Biotechnol. 2016, 14, 163-168. [CrossRef]

93. Lukman, A.I.; Gong, B.; Marjo, C.E.; Roessner, U.; Harris, A.T. Facile synthesis, stabilization, and anti-bacterial performance of discrete Ag nanoparticles using Medicago sativa seed exudates. J. Colloid. Interface Sci. 2011, 353, 433-444. [CrossRef] [PubMed]

94. Xia, Q.H.; Zheng, L.P.; Zhao, P.F.; Wang, J.W. Biosynthesis of silver nanoparticles using Artemisia annua callus for inhibiting stem-end bacteria in cut carnation flowers. IET Nanobiotechnol. 2017, 11, 185-192. [CrossRef]

95. Kharat, S.N.; Mendhulkar, V.D. Synthesis, characterization and studies on antioxidant activity of silver nanoparticles using Elephantopus scaber leaf extract. Mater. Sci. Eng. C Mater. Biol. Appl. 2016, 62, 719-724. [CrossRef] [PubMed]

96. Nagaich, U.; Gulati, N.; Chauhan, S. Antioxidant and antibacterial potential of silver nanoparticles: Biogenic synthesis utilizing apple extract. J. Pharm. (Cairo) 2016, 2016, 7141523. [CrossRef]

97. Yugandhar, P.; Haribabu, R.; Savithramma, N. Synthesis, characterization and antimicrobial properties of green-synthesised silver nanoparticles from stem bark extract of Syzygium alternifolium (Wt.) Walp. 3 Biotech 2015, 5, 1031-1039. [CrossRef]

98. Sanjenbam, P.; Gopal, J.V.; Kannabiran, K. Anticandidal activity of silver nanoparticles synthesized using Streptomyces sp.VITPK1. J. Mycol. Med. 2014, 24, 211-219. [CrossRef] [PubMed]

99. Vyshnava, S.S.; Kanderi, D.K.; Panjala, S.P.; Pandian, K.; Bontha, R.R.; Goukanapalle, P.K.; Banaganapalli, B. Effect of silver nanoparticles against the formation of biofilm by pseudomonas aeruginosa an in silico approach. Appl. Biochem. Biotechnol. 2016, 180, 426-437. [CrossRef] [PubMed] 